\title{
A diverse assemblage of Ophiostoma species, including two new taxa on eucalypt trees in South Africa
}

\author{
G. Kamgan Nkuekam ${ }^{1 *}$, Z. Wilhelm de Beer ${ }^{2}$, M.J. Wingfield ${ }^{1}$, J. Roux $^{1}$ \\ 1\&2 Department of Microbiology and Plant Pathology, DST/NRF Centre of Excellence in Tree \\ Health Biotechnology, Forestry and Agricultural Biotechnology Institute (FABI), University of \\ Pretoria, Pretoria, South Africa.
}

Corresponding author: Jolanda.Roux@fabi.up.ac.za, phone number: +27-12 420 3938/9, fax number: $+27-124203960$

\begin{abstract}
Fungi in the Ophiostomatales include important pathogens of trees as well as agents of wood stain, reducing the economic value of timber. They rely on insects, such as bark beetles, for dispersal and are commonly associated with wounds on trees. Although Ophiostoma spp. Have been reported from eucalypt wood chips in South Africa, very little is known about the diversity of the Ophiostomatales or their insect associates, on plantation grown Eucalyptus spp. The aim of this study was to consider the diversity and distribution of the Ophiostomatales infecting fresh wounds on Eucalyptus trees in the country. Additionally, knowledge regarding their association with nitidulid beetles, which have previously been shown to carry Ophiostoma spp. was sought. Surveys were conducted in five provinces were Eucalyptus spp. are commonly grown and the fungi collected were identified using morphological comparisons and multigene sequence phylogenies. Of the 139 isolates collected, five Ophiostoma spp. were identified including O. quercus, O. tsotsi and $O$. tasmaniense. These were from cut stumps as well as the nitidulid beetles Brachypeplus depressus and Carpophilus spp. In addition, two new taxa in the O. stenoceras - Sporothrix schenkii complex were identified from Eucalyptus trees infested by Phoracantha semipunctata. The two new taxa are described as $O$. candidus sp. nov., and $O$. canescensis sp. nov., respectively. Results of this study clearly show that the diversity and ecology of Ophiostoma spp. on Eucalyptus trees in South Africa is poorly understood and further studies are required to determine the possible economic relevance of these fungi.
\end{abstract}

Keywords Ophiostomatoid fungi, Ophiostomatales, insect vectors, Sporothrix, plantation forestry. 


\section{Introduction}

The Ophiostomatales (Ascomycetes) includes the three fungal genera Ceratocystiopsis Upadhyay \& Kendrick with Hyalorynocladiella Upadhyay \& Kendrick anamorphs, Grosmannia Goidanich with Leptographium Lagerberg \& Melin anamorphs and Ophiostoma H. \& P. Sydow with Pesotum Crane and Sporothrix Hektoen \& Perkins anamorphs (Zipfel et al. 2006). The sexual states of these fungi are characterized by mostly black ascomata with long erect necks giving rise to sticky spore drops that facilitate dispersal by insects (Malloch and Blackwell 1993). In the anamorph states, fruiting structures including synnemata, such as are found in Pesotum and mononematous conidiophores in Leptographium spp., Hyalorhinocladiella and Sporothrix spp. (Crane and Schoknecht 1973; Wingfield et al. 1991). Although more clearly defined than a decade ago, the taxonomy of fungi in the Ophiostomatales remains in a state of flux. For example, there is emerging evidence that the genus Ophiostoma, which comprises the largest number of species, is a generic aggregate including groups of species that represent distinct monophyletic lineages (De Beer and Wingfield 2006).

Species in the Ophiostomatales often are extremely variable in their culture morphology on artificial media, making their identification very difficult. Species in the $O$. piceae complex, for example, have been found in numerous studies to have variable culture morphology on artificial media, making morphological delineation of species in the complex subjective (Przybyl and De Hoog 1989; Brasier and Kirk 1993; Halmschlager et al. 1994; Kamgan Nkuekam et al. 2008a, b). Further more, there is substantial evidence that DNA-based studies using the ITS gene region is not sufficient to separate closely related species in the $O$. piceae complex (Chung et al. 2006; Kamgan Nkuekam et al. 2008a). Therefore, the trend in recent years has been to use sequence data for a protein coding genes, such as the beta tubulin gene, which resolve species in the Ophiostomatales more appropriately (Chung et al. 2006; Kamgan Nkuekam et al. 2008a). In a recent study, Grobbelaar et al. (2009) used a multigene phylogeny including four gene regions to separates species of the $O$. piceae complex. The study led to the discovery and description of $O$. tsotsi Grobbelaar, Z.W. de Beer \& M.J. Wingf., a cryptic species that was treated for many years collectively with O. quercus (Georgev.) Nannf. (Grobbelaar et al. 2010a).

The Ophiostomatales includes a number of important tree pathogens and agents of sapstain in lumber. Important pathogens include the Dutch elm disease fungi, O. ulmi (Buisman) Nannf. and O. novo-ulmi Brasier (Gibbs 1978; Brasier 2000) and Leptographium wageneri (Goheen \& F.W. Cobb) T.C. Harr. (Cobb 1988; Harrington 1993). Most species of Ophiostoma, however, result in 
staining of the sapwood, particularly in conifers that can reduce its commercial value (Seifert 1993). Amongst these fungi, O. minus (Hedgcock) H. \& P. Sydow, O. pluriannulatum (Hedgcock) H. \& P. Sydow and O. piceae (Munch) Syd. \& P. Syd. are amongst the most important sapstain species of lumber in the Northern Hemisphere (Seifert 1993).

Fungi in the Ophiostomatales require wounds to infect their hosts and are commonly vectored by arthropods that either visit wounds on trees or produce these wounds themselves. Of these insects, bark beetles are by far the best known for their mutualistic relationship with these fungi (Whitney 1982; Paine et al. 1997; Six 2003; Kirisits 2004). However, a wide variety of insects, such as cerambycid beetles (Mathiesen-Käärik 1953; Jacobs and Wingfield 2001; Jacobs and Kirisits 2003), weevils (Mathiesen-Käärik 1953; Jacobs and Wingfield 2001; Kirisits 2004) and phoretic mites carried by bark beetles (Bridges and Moser 1986; Moser 1997; Malloch and Blackwell 1993) are also associated with these fungi.

South Africa has limited natural timber resources. The country mostly has a grassland vegetation type with native forests covering about $0.56 \%$ of the total land area in the country (Lawes et al. 2004). This exerts great pressure on the available natural tree resources, as timber suitable for construction, fire wood and other wood products are limited in the country. Plantations of non-native trees were established in South Africa in the last century in an attempt to alleviate the demand for timber and wood products (Anonymous 2008). These plantation areas now comprise approximately 1.3 million ha (1.2\% of the country surface area). The plantations include non-native Eucalyptus spp. that cover approximately 0.58 million ha, (39\%) of the total area planted (Anonymous 2008).

Reports of ophiostomatoid fungi occurring on Eucalyptus spp. are limited. Ophiostoma quercus (Georgev.) Nannf., has been reported from E. grandis trees in Uruguay (Harrington et al. 2001) and most recently O. tsotsi was reported from Eucalyptus pulpwood chips in China (Grobbelaar et al. 2010b). There have been relatively few reports of these fungi on Eucalyptus from Africa and these include O. quercus on E. grandis (De Beer et al. 2003a) and O. stenoceras (Robak) Nannf. on Eucalyptus spp. in South Africa and from soil in eucalypt plantations in Kenya (De Beer et al. 2003b). Ophiostoma tsotsi was found on Eucalyptus spp. in South Africa as well as in Malawi (Grobbelaar et al. 2009). Other Ophiostoma spp. known from Africa are confined to reports from South Africa where they are known either from non-native bark beetles infesting Pinus spp. (Zhou et al. 2001, 2006), or from indigenous trees (De Beer et al. 2003a, b; Kamgan Nkuekam et al. 2008a; Roets et al. 2008, 2010). Although not associated with tree diseases in South Africa, Ophiostoma spp. reported from the country form part of an economically important group of fungi associated with sapstain of timber, reducing its commercial value substantially (De Beer et al. 2003a). 
The aim of this study was to increase the base of knowledge pertaining to fungi in the Ophiostomatales on plantation-grown Eucalyptus spp. in South Africa. Collection were focused on freshly made wounds on trees and those from nitidulid beetles (Coleoptera: Nitidulidae) that visit these wounds. Morphological characteristics, mating studies and phylogenetic inference based on DNA sequence data were used to identify these fungi.

\section{Materials and methods}

\section{Collection of samples}

\section{Fungal isolates from trees}

To investigate the occurrence of Ophiostomatoid fungi on eucalypts in South Africa, collections were made from freshly cut stumps, since wounds are known to be infection sites for these fungi. Wounds are also commonly visited by nitidulid beetles, making it possible to collect both ophiostomatoid fungi and their possible nitidulid vectors. Collections were made between February 2007 and November 2008 in most of the commercial eucalypt growing areas of the country. All overall aim was to collect material from as many different geographical and climatic areas of the country as possible. Samples were mainly collected from harvesting wounds (stumps) of felled trees as well as from logs lying on the plantation floor. However, where damage to the stems of trees, caused by wood boring beetles was observed, samples were also collected. Areas sampled included the Soutpansberg and Tzaneen areas (Limpopo Province), Lothair and Sabie (Mpumalanga Province), George, Cape-Town and Stellenbosch (Western Cape Province), Kumbu and Lotebeni (Eastern Cape Province) and localities near Kwambonambi and Pietermaritzburg (KwaZulu Natal Province).

Pieces of bark and wood were collected from wounds, especially those with bark flaps, and stored in brown paper bags after they had been inspected with a 20X magnifying hand lens for the presence of fruiting bodies (ascomata or conidiophores) resembling those of the ophiostomatoid fungi. All the samples were transported to the laboratory in plastic bags to retain moisture, and processed following the methods described by Kamgan Nkuekam et al. (2008a, 2010a). Replicates of each pure isolate obtained were deposited in the culture collection (CMW) of the Forestry and Agricultural Biotechnology Institute (FABI), University of Pretoria, South Africa. Representative specimens were also deposited with the Centraalbureau voor Schimmelcultures (CBS), Utrecht, 
Netherlands. Dried specimens of representative isolates were deposited in the National Collection of Fungi (PREM), Pretoria, South Africa.

\section{Collection of insects and isolations}

Nitidulidae were collected from underneath bark flaps on cut stumps and wounds on Eucalyptus spp. This was done using an aspirator pooter (Fergusson 1982). Living insects were transferred to cylindrical labeled glass containers containing a piece of tissue paper that served to reduce contact and conflict among insects. In the laboratory, collected insects were inactivated by cooling the glass containers in a box containing ice. The insects were grouped according to morphological characteristics using an Axiocam dissection microscope (Carl Zeiss Ltd., Germany). Representatives of each insect group were preserved in 70\% ethanol prior to identification, by Dr. Andrew Cline, Senior Insect Biosystematist, Plant Pest Diagnostics Center, California Department of Food \& Agriculture, USA.

Isolation of fungi from insects was done by crushing individual specimens between two slices of carrot and incubating them for five days at $25^{\circ} \mathrm{C}$ (Moller and Devay 1968; Heath et al. 2009). Fungi were isolated by transferring fruiting bodies (mycelium, ascomata, ascospores) growing on the carrots to $2 \%$ malt extract agar (MEA: $20 \mathrm{~g} / \mathrm{L}$ malt extract and $15 \mathrm{~g} / \mathrm{L}$ agar, Biolab, Midrand, South Africa and $1000 \mathrm{ml}$ sterile deionised water) containing $0.05 \mathrm{~g} / \mathrm{L}$ of the antibiotic streptomycin sulphate (SIGMA-ALDRICH, Steinheim, Germany).

\section{Morphological characterization}

All isolates resembling species of Ophiostomatales were characterized based on commonly used characteristics for this group. Single drops of conidia, ascospores or small pieces of mycelium were transferred from pure cultures to Oatmeal agar media (OMA: $30 \mathrm{~g}$ Oats, $20 \mathrm{~g}$ Biolab agar and 1000 $\mathrm{mL}$ deionised water) to promote sporulation. Cultures were incubated at $25^{\circ} \mathrm{C}$ until sporulation and then grouped into morphotypes based on colour (Rayner 1970) and macro-morphology. Fruiting structures from selected isolates representing each morphotype were mounted in $80 \%$ lactic acid on microscope slides and studied using a Zeiss Axiocam light microscope (München-Hallbergmoos, Germany). Fifty measurements of all characteristic morphological features were made for isolates chosen as the types of new species and ten measurements were made for additional isolates. The means were then calculated for relevant morphological structures. Measurements were noted as (minimum -) mean minus st. dev. - mean plus st. dev. (- maximum). 
Scanning electron microscopy was used to observe fruiting bodies (conidia, conidiophores) of the asexual states of the fungi. For this purpose, specimens were prepared as described by Grobbelaar et al. (2009). The specimens were critical point dried (Bio-Rad E3000, Watford, England), then mounted and coated with gold in a sputter coater (Emitech K550X, Ashford, England) and examined using a JEOL JSM-840 scanning electron microscope (JEOL, Tokyo, Japan).

\section{Growth in culture}

Three isolates of each new species identified in this study were used for growth studies in culture. A disk of agar ( $9 \mathrm{~mm}$ diam.) bearing mycelium of the test isolates was transferred from the actively growing margins of seven-day-old cultures and placed upside down at the centres of $90 \mathrm{~mm}$ Petri dishes containing $2 \%$ MEA. Five replicate plates were used for each isolate at each growth temperature considered. Two diameter measurements, perpendicular to each other, were taken daily for each colony and the averages of ten diameter measurements for each temperature were computed.

\section{DNA sequence comparisons}

Representative isolates of each morpho-group were selected for DNA sequence comparisons. Single spore drops collected from pure cultures were grown on 2\% MEA for 7-10 days. Mycelium was scraped from the surface of the actively growing cultures and then transferred to $1.5 \mathrm{~mL}$ Eppendorf tubes using a sterile hypodermic needle. DNA was extracted using PrepMan Ultra Sample Preparation Reagent (Applied Biosystems, California, USA) following the manufacturer's instructions.

The internal transcribed spacer regions (ITS1, ITS4) and 5.8S gene of the ribosomal RNA operon were amplified with an Eppendorf Mastercycler (Merck, Germany) using primers ITS1 and ITS4 (White et al. 1990). Part of the $\beta$-tubulin (BT) gene and the transcription elongation factor- $1 \alpha$ (TEF) gene were amplified using the primers T10 (O'Donnell and Cigelnik 1997) and Bt2b (Glass and Donaldson 1995), and EF1F and EF2R (Jacobs et al. 2004), respectively.

The PCR reaction mixtures as well as the thermal cycling conditions were the same as those described previously (Kamgan Nkuekam et al. 2008a, b). An aliquot of $5 \mu$ lof the PCR products were stained with GelRed ${ }^{\mathrm{TM}}$ Nucleic Acid Gel stain (Biotium, Hayward, USA), separated on a 1\% agarose gel and visualized under UV light. PCR products were purified using Sephadex G-50 Gel (Sigma-Aldrich), following the manufacturer's instructions. Subsequently, the concentrations of the 
purified PCR products were determined using a Nanodrop ND-1000 Spectrophotometer (Nanodrop Technologies, Rockland, USA). Sequencing reactions were performed using the Big Dye cycle sequencing kit with Amplitaq DNA polymerase, FS (Perkin-Elmer, Warrington, UK) following the manufacturer's protocols on an ABI PRISM 3100 Genetic Analyzer (Applied Biosystems). Sequencing PCRs were prepared as described by Kamgan Nkuekam et al. (2008a) and both DNA strands were sequenced.

\section{Compilation of sequence data sets}

Contigs of both sequenced strands for each isolate and each gene region were assembled using Sequence Navigator 1.01 (ABI PRISM, Perkin Elmer). Additional sequences of related species in the Ophiostomatales were obtained from the GenBank database (http://www.ncbi.nlm.nih.gov) for comparisons. Sequences were aligned using the E-INS-i option in the online version of MAFFT 6 (Katoh and Toh 2008). To avoid the inclusion of large numbers of identical sequences in the phylogenetic analyses, parts of the beta tubulin region for all isolates collected were sequenced and grouped based on haplotypes using MEGA 4.0.1 (Tamura et al. 2007). For each BT haplotype, only a few representatives were included in the analyses of the ITS and TEF data sets.

\section{Phylogenetic analyses}

Phylogenetic analyses of the ITS, TEF and BT data sets were performed independently of each other. This was done to avoid masking important information and because reference sequences are not available for the same sets of isolates for all gene regions. For each data set, maximum parsimony (MP), Bayesian analyses (MB), and maximum likelihood (ML) analyses were done. However, since the sequence data for intron 5 of the BT gene varies greatly between different species groups, the dataset was treated in subsets in order to obtain improved alignments for species definition. MP analyses were performed in a similar manner for both BT data sets in PAUP $4.0 b 10$ (Swofford 1998), using the following settings: 100 random sequence addition replicates, tree bisection-recognition (TBR) branch swapping, and 'multrees' option in effect. Confidence levels of the MP phylogenies were estimated with the bootstrap method (1000 replications).

Bayesian analyses based on Markov Chain Monte Carlo (MCMC) were performed with MrBayes 3.1.2 (Huelsenbeck and Ronquist 2001) as outlined previously (Kamgan Nkuekam et al 2010a). Appropriate substitution models were determined using the Akaike Information Criterion (AIC) in MrModeltest 2.2 (http://www.abc.se/ nylander/). The model applied to both ITS and TEF was $(\mathrm{GTR}+\mathrm{I}+\mathrm{G})$, while for the two subsets of BT data it was $(\mathrm{HKY}+\mathrm{G})$ and $(\mathrm{HKY}+\mathrm{G})$ respectively. 
Burn-in values were determined using Tracer 1.4 (http://beast.bio.ed.ac.uk/Tracer) to discard trees that formed before the point of convergence, and the posterior probability in the majority rule consensus trees were calculated by MCMC sampling in MrBayes V3.1.2, using the best-fit model of evolution mentioned above.

Maximum likelihood (ML) analyses were conducted online using PhyML 3.0 (Guindon and Gascuel 2003). The AIC was used in Modeltest 3.7 (Posada and Crandall 1998) to select appropriate substitution models for the three data sets. For ITS, the selected model was GTR $+\mathrm{I}+\mathrm{G}$ (gamma Shape parameter=1.0169; Pinvar=0.2617), for the TEF, it was GTR $+\mathrm{I}+\mathrm{G}$ (gamma shape parameter=2.0444; Pinvar=0.1411), while for the two subsets of BT it was TVM $+\mathrm{G}$ (gamma Shape parameter $=0.1978)$ and $\mathrm{HKY}+\mathrm{G}$ (gamma Shape parameter $=0.1612)$, respectively.

\section{Results}

\section{Collection of samples}

\section{Fungal isolates from trees}

A total of 115 isolates resembling species in the Ophiostomatales were obtained from eucalypt trees in this study. More than 300 trees were sampled in the process (Table 1). Samples were obtained from the stumps of recently felled trees, fresh logs lying in the field and from the tunnels of Phoracantha spp., in standing trees. Isolates were obtained from all areas sampled and included $E$. grandis W. Hill ex Maiden (Tzaneen, Sabie, Kumbu and Lotebeni), E. saligna Sm. (Cape Town, Soutpansberg), E. diversicolor F. Muell (Cape Town), E. cloeziana F. Muell (Soutpansberg), E. maculata Hook. (Soutpansberg), stumps of an unknown Eucalyptus species (George), logs lying on the plantation floor (Stellenbosch) and at a harbor (Cape Town) (Table 1). The climatic regions where samples were collected included Mediterranean (Cape Town, Stellenbosch) Temperate (Lotebeni, Kumbu) and Subtropical (Kwa- Mbonambi, Tzaneen, Soutpansberg) regions and included winter (Cape Town, Stellenbosch), year-round (George) and summer (KwaZulu Natal, Mpumalanga, Limpopo Province) rainfall areas.

\section{Collection of insects and isolations}

Nitidulid beetles were found in most of the areas sampled. A total of 271 insects were collected from stumps of various Eucalyptus trees and they could be broadly divided into two groups based 
on morphology. These were Brachypeplus sp. (140 specimens), identified as B. depressus Erichson, and a Carpophilus sp. identified as $C$. humeralis Fabricius (120 specimens). Some insect specimens (11 insects) were recognized as a Carpophilus sp. but could not be identified to species level. Of the 24 Ophiostoma isolates obtained from insects, 13 were from $B$. depressus while 11 were from Carpophilus spp. (Table 1).

\section{Morphological characterization}

Three morphological groups were found among the ophiostomatoid fungi collected. Morpho-group A, comprising 123 isolates, produced Pesotum anamorphs and Sporothrix syn-anamorphs on OMA. They also produced limited numbers of ascomata with long erect necks exuding slimy masses of spores, scattered over the colony surface. Morpho-group B, consisted of eight isolates with white cultures and ascomata produced abundantly and embedded within the mycelium mat. Morphogroup $\mathrm{C}$ consisted of eight isolates with grey-coloured cultures and ascomata with very short necks deprived of ostiolar hyphae, produced in a thick mycelial mat by some strains.

\section{Compilation of sequence data and phylogenetic analyses}

All isolates sequenced produced fragments of approximately 400 bps for the BT gene region. Blast searches in the GenBank data base showed that all isolates of morpho-group A were members of the $O$. piceae complex while isolates of morpho-group B and morpho-group $\mathrm{C}$ belonged to the $\mathrm{S}$. schenckii-O. stenoceras complex. Furthermore, the morpho-group A isolates all had intron 4 and lacked intron 5, while isolates from morpho-groups B and $\mathrm{C}$ lacked intron 4 but presented intron 5. The BT data for the three groups of isolates were thus analyzed separately in two subsets to obtain improved alignments for species definition.

Comparisons of the BT sequence data for the O. piceae subset of isolates from South Africa with those of related Ophiostoma spp. from GenBank, resulted in a total of 238 characters including gaps, with 142 constant characters, 11 parsimony uninformative characters and 85 parsimony informative characters. Comparisons of the BT sequence data for the O. stenoceras subset of isolates with those of related Ophiostoma spp. from GenBank resulted in a total of 269 characters including gaps, with 145 constant characters, 3 parsimony uninformative characters and 121 parsimony informative characters.

Maximum parsimony analyses of the BT data set of the $O$. piceae subset of isolates generated 308 trees. The consistency indices (CI) and retention index (RI) values were 0.617 and 0.912 respectively. Analyses of the BT data set of the O. stenoceras subset of isolates generated 648 
trees, with CI and RI values of 0.494 and 0.874 respectively. For each data set, a 50\% majority rule tree obtained from Bayesian analyses and a bootstrap tree was also obtained from a MP as well as from maximum likelihood analyses (ML). For each data set, a ML tree is presented (Figs. 1 and 2) indicating at the relevant node, MP bootstrap values, Bayesian posterior probabilities, and ML bootstrap values respectively.

In the BT tree (Fig. 1), isolates representing the $O$. piceae subset were resolved into three groups. The first set of isolates grouped with strains of $O$. quercus. The second set of isolates grouped with strains of $O$. tsotsi, while the third set of isolates grouped with strains of $O$. tasmaniense (Fig. 1). In the BT tree representing the O. stenoceras data set (Fig. 2), isolates from South Africa could be resolved into two clades, well supported at the nodes and clearly distinct from other Ophiostoma reference strains. Isolates representing morpho-groups B and C resided in well resolved clades with good statistical support.

Representatives of each haplotype found in the BT data set of the O. piceae subset of isolates were selected for phylogenetic analyses of the TEF data set. Comparisons of the TEF data set of the $O$. piceae subset of isolates with those of related Ophiostoma spp. from GenBank, resulted in a total of 520 characters including gaps, with 95 constant characters, 18 parsimony uninformative characters and 407 parsimony informative characters. Maximum parsimony analyses of the TEF data set generated 1122 best trees, with a CI and RI values of 0.661 and 0.932 respectively. For the TEF data set, a 50\% majority rule tree obtained from Bayesian analyses and a bootstrap tree was also obtained from a MP as well as from ML (Fig. 3) analyses.

Results of analyses of the TEF data (Fig. 3) were similar to those of the BT data set. Representatives of the $O$. piceae subset of isolates were again resolved into three clades. One set of isolates grouped with strains of $O$. quercus, the second set grouped with strains of $O$. tsotsi, while the third set of isolates grouped with strains of $O$. tasmaniense.

For the ITS data set, representatives of each morpho-group found in the survey were selected for phylogenetic analyses. Comparisons of the ITS data set with those of related Ophiostoma spp. from GenBank resulted in a total of 799 characters including gaps, with 216 constant characters, 80 parsimony uninformative characters and 503 parsimony informative characters. Maximum parsimony analyses of the ITS data set generated 2069 best trees, with a CI and RI values of 0.566 and 0.865 respectively. For the ITS data set, a 50\% majority rule tree obtained from Bayesian analyses and a bootstrap tree was also obtained from a MP as well as from ML analyses (Fig. 4).

The two subsets of Ophiostoma species, identified based on BT sequences and the presence and/or absence of introns 4 and 5, could clearly be recognized within the ITS tree. The $O$. piceae complex subset resided in top half of the tree, while the S. schenckii-O. stenoceras complex was 
confined to the lower part of the tree (Fig. 4). Isolates representing morpho-group A clustered with those of $O$. quercus, $O$. tsotsi and $O$. tasmaniense, but the clades representing these species were not well resolved. Isolates representing morpho-group B and morpho-group $\mathrm{C}$ formed two different clades within the $S$. schenckii-O. stenoceras complex. These clades were clearly separated from other Ophiostoma reference isolates and they were statistically well supported (Fig. 4).

\section{Taxonomy}

Based on morphological examination and phylogenetic analyses using the ITS and BT gene regions, two Ophiostoma spp. from South Africa emerged as distinct and previously undescribed species within the S. schenckii-O. stenoceras complex of the Ophiostomatales. The following descriptions are provided for them.

\section{Ophiostoma candidum Kamgan-Nkuekam, Jol. Roux \& Z. W. de Beer sp. nov. (Fig. 5).}

Etymology: The name refers to the dazzling white colony color of the fungus on artificial media.

Coloniae albae tegetibus mycelii crassis, in MEA ut videtur madidae; usque ad $11.5 \mathrm{~mm}$ diametro in 10 diebus in MEA in $25^{\circ} \mathrm{C}$. Crescit optime in $25^{\circ} \mathrm{C}$; non crescit in $10^{\circ} \mathrm{C}$ nec $30^{\circ} \mathrm{C}$ nec $35^{\circ} \mathrm{C}$. Ascomata in superficie coloniae dispersa et in mycelio inclusa, guttas sporarum albocremeas facientes. Colla ascomatum nigra hyphis ostiolaribus divergentibus. Bases ascomatum nigrae globosae pilis hypharum. Bases collorum laeves. Ascosporae reniformes hyalinae non septatae (3.5) 4-4.5 (-5) x (0.99-) 1-1.5 (-1.7) $\mu \mathrm{m}$. Anamorpha Sporothrix conidiophoris hyalinis cylindricis apicem versus contractis, cum denticulis prominentibus. Conidia non septata, hyalina oblonga interdum acerosa nonnulla valde curvata (1.5-) 1.5-2 (-2.5) x (0.3-) 0.34-0.5 (-0.6) $\mu \mathrm{m}$.

Colonies white, with thick mycelial mat, with a wet appearance on MEA. Reverse Buff (19'’d). Colony diameters reaching $11.5 \mathrm{~mm}$ in 10 days on MEA at $25^{\circ} \mathrm{C}$. Optimal growth at $25^{\circ} \mathrm{C}$. No growth at $10^{\circ} \mathrm{C}$ and at $30^{\circ} \mathrm{C}$ or $35^{\circ} \mathrm{C}$. Ascomata scattered over the colony surface and embedded within mycelium on agar plates, producing white, creamy spore drops at the apices of the necks. Ascomatal necks black (270.5-) 506-875 (-970.5) $\mu \mathrm{m}$ long. Ascomatal bases black, globose (84.5-) 124.5-184.5 (-206) $\mu \mathrm{m}$ long and (90-) 119-182 (-233) $\mu \mathrm{m}$ wide, with hyphal hairs. Neck bases smooth (24-) 29.5-41 (-51) $\mu \mathrm{m}$ wide, middle of necks (16.5-) 19-25 (-27.5) $\mu \mathrm{m}$ wide, tips of necks (9-) 11.5-16 (-22) $\mu \mathrm{m}$ wide. Ostiolar hyphae divergent (16-) 22.5-34 (-39). Asci not seen, 
evanescent, deliquescing early in the development. Ascospores reniform, aseptate, hyaline (3.5-) 4$4.5(-5) \times(0.99-) 1-1.5(-1.7) \mu \mathrm{m}$.

Anamorph: Sporothrix, conidiophores hyaline, cylindrical, tapering towards the apex, (12.5) 17.5-43.5 (-61) x (1.5-) 1.9-2.5 (-3) $\mu \mathrm{m}$, prominent denticles present. Conidia aseptate, hyaline, oblong, occasionally acerose, distinctly curved in some cases (1.5-) 1.5-2 (-2.5) x (0.3-) 0.34-0.5 (0.6) $\mu \mathrm{m}$.

Specimens examined: South Africa, Limpopo Province, Goedehoop area of the Soutpansberg, isolated from wound on Eucalyptus cloeziana tree struck by lightning, 21/06/2007, G. Kamgan Nkuekam and Jolanda Roux, holotype PREM ***, living culture CMW26484, $\mathrm{CBS} * * * *$

Additional specimens: South Africa, Limpopo Province, Goedehoop area of the Soutpansberg, isolated from wound on Eucalyptus cloesiana tree struck by lightning, 21/06/2007, G. Kamgan Nkuekam \& J. Roux, holotype PREM ***, living culture CMW26483, CBS****; isolated from wound on Eucalyptus cloesiana tree struck by lightning, 21/06/2007, G. Kamgan Nkuekam \& J. Roux, holotype PREM ***, living culture CMW26485, CBS****

Ophiostoma fumeum Kamgan-Nkuekam, Jol. Roux \& Z. W. de Beer sp. nov. (Fig. 6). Etymology: The name refers to the smoky grey colony color of the fungus on artificial media.

Coloniae fumeae tegetibus mycelii crassis in MEA; usque ad $16.5 \mathrm{~mm}$ diametro in 10 diebus in MEA in $25^{\circ} \mathrm{C}$. Crescit optime in $30^{\circ} \mathrm{C}$; non crescit in $10^{\circ} \mathrm{C}$. Ascomata in cultura serotina in mycelio inclusa, guttas sporarum albocremeas facientes. Colla ascomatum nigra sine hyphis ostiolaribus. Bases ascomatum nigrae globosae pilis hypharum. Bases collorum laeves. Ascosporae allantoideae hyalinae non septatae (4-) 4.5-5.5 (-6) x (1.3-) 1.4-1.7 (-1.9) $\mu \mathrm{m}$. Anamorpha Sporothrix conidiophoris hyalinis cylindricis cum denticulis prominentibus. Conidia non septata, hyalina oblonga vel cylindrica (1-) 1.5-2 (-2.5) x (0.4-) 0.5-0.6 (-0.8) $\mu \mathrm{m}$.

Colonies smoke grey (21',', d), with thick mycelium mat on MEA. Reverse smoke grey $\left(21^{\prime,}, \mathrm{d}\right)$. Colony diameters reaching $16.5 \mathrm{~mm}$ in 10 days on MEA at $25^{\circ} \mathrm{C}$. Optimal growth at $30^{\circ} \mathrm{C}$. No growth at $10^{\circ} \mathrm{C}$. Ascomata produced late in culture and embedded within mycelium, producing white, creamy spore drops at the neck apices. Ascomatal necks black (50.5-) 77-119.7 (145) $\mu \mathrm{m}$ long. Ascomatal bases black, globose (81-) 103-144.5 (-165) $\mu \mathrm{m}$ long and (97-) 116-164 (186.5) $\mu \mathrm{m}$ wide, with hyphal hairs. Neck base smooth, (31-) 30-43 (-50) $\mu \mathrm{m}$ wide. Ostiolar hyphae 
absent. Asci not seen, evanescent, deliquescing early in the development. Ascospores allantoid, aseptate, hyaline (4-) 4.5-5.5 (-6) x (1.3-) 1.4-1.7 (-1.9) $\mu \mathrm{m}$.

Anamorph: Sporothrix, conidiophores hyaline, cylindrical, (2.2-) 4-7 (-10.5) x (0.46-) 0.52$0.67(-0.75) \mu \mathrm{m}$, prominent denticles present. Conidia aseptate, hyaline, oblong, to cylindrical (1-) $1.5-2(-2.5) \times(0.4-) 0.5-0.6(-0.8) \mu \mathrm{m}$.

Specimens examined: South Africa, Limpopo Province, Soutpansberg area, isolated from Eucalyptus cloeziana infested by Phoracantha beetles, 21/06/2007, G. Kamgan Nkuekam and J. Roux, holotype PREM ****, living culture CMW26813, CBS****

Additional specimens: South Africa, Limpopo province, Soutpansberg area, isolated from Eucalyptus cloeziana infested by Phoracantha beetles, 21/06/2007, G. Kamgan Nkuekam and J. Roux, paratype, living culture CMW26816/PREM ****, isolated from Eucalyptus spp. infested by Phoracantha beetles in Zambia, Copperbelt Province, J. Roux, paratype, living culture CMW26818/PREM ****.

\section{Discussion}

Results of this study have shown that Ophiostoma spp. occur widely on Eucalyptus trees and logs in South Africa. Five Ophiostoma spp. were identified. Two of these were previously undescribed species in S. schenckii-O. stenoceras complex for which the names $O$. canescensis and $O$. candidus were provided. O. tasmaniense was found for the first time from outside Australia, while the geographic and host ranges for $O$. quercus and $O$. tsotsi were expanded substantially.

Ophiostoma canescensis and O. candidus, the two new taxa described in this study are phylogenetically related and morphologically similar to species in the S. schenckii-O. stenoceras complex. Most members of this complex have white or grey cultures, Sporothrix anamorphs and allantoid to reniform to orange section-shaped ascospores (De Hoog 1974; De Beer et al. 2003b). O. candidus and $O$. canescensis both share these morphological characteristics.

Ophiostoma candidus and O. canescensis described in this study formed distinct clades within the $S$. schenckii-O. stenoceras complex. The complex includes nine species described from arthropod-infested Protea infructescences (Roets et al. 2006, 2008, 2010), 11 species associated with soil (Zhou et al. 2006; Marimon et al. 2007; De Meyer et al. 2008; Madrid et al. 2010), five from hardwoods (De Beer et al. 2003b; Aghayeva et al. 2004, 2005; De Meyer et al. 2008), four from conifers (Aghayeva et al. 2004; Zhou et al. 2006; De Meyer et al. 2008), and four human pathogens (Marimon et al. 2007, 2008). Fifteen of these species, including all those from the Proteaceae are known only from Southern Africa. Four of the South African species have some 
form of association with Eucalyptus spp. O. stenoceras was isolated from E. smithii R.T. Baker, E. grandis and E. fastigata Deane \& Maiden in South Africa and soil from a Eucalyptus plantation in Kenya (De Beer et al. 2003b). Sporothrix lignivora was first described from Eucalyptus utility poles (De Meyer et al. 2008), S. variecibatus from decaying Eucalyptus leaves and mites (Roets et al 2008), and S. schenckii from Eucalyptus wood stacks used to strengthen tunnels in gold mines (Findlay 1970). O. candidus was isolated from a E. cloeziana tree struck by lightning in the Limpopo Province, and O. canescensis from a Eucalyptus trees infested with the cerambycid beetle Phoracantha semipunctata in Limpopo Province and Zambia.

It has been suggested that possibly all the species in the S. schenckii-O. stenoceras complex from Protea infructescences are vectored by and have some form of association with arthropods, especially mites (Roets et al. 2007, 2009). The only other species in this complex that was isolated from an arthropod, in this case a root-infesting bark beetle, is O. aurorae (Zhou et al. 2006). However, this species was found with the beetle only in a single location during an extensive survey (Zhou et al. 2001), suggesting that the association with the beetle is not fixed. Another species, $S$. variecibatus, was isolated from a mite from Protea, but was also isolated from a decaying Eucalyptus leaf at the same location (Roets et al. 2008). The fact that O. canescensis was isolated in the present study from the same host and beetle galleries a few thousand kilometers apart, suggests that could be some form of association between the host tree, fungus and insect. In this case, and given their close association with Ophiostomatoid fungi (Malloch and Blackwell 1993), is probable that mites are involved in this association. Considering the geographical distribution, host and possible arthropod associations, it appears that Southern Africa could represent a centre of diversity for species in the S. schenckii-O. stenoceras complex.

The three known species of Ophiostoma, O. quercus, O. tsotsi and Otasmaniense, found in the present study are members of the $O$. piceae complex. The so-called $O$. piceae complex was first recognized to comprise nine species of fungi infecting either hardwood or coniferous trees (Harrrington et al 2001). In recent years, the number of species in the complex has expanded substantially, and it is now recognized to consist of at least two major lineages, one of which includes only of hardwood-infesting species (Harrington et al. 2001; Grobbelaar et al. 2009, 2010a; Linnakoski et al. 2009; Kamgan Nkuekam et al. 2008b, 2010a). All three species found on Eucalyptus in this study form part of this hardwood lineage.

It was not surprising to find O. quercus, on Eucalyptus trees in this study. The fungus was first reported from South Africa on native Olinia sp. and on E. grandis and Quercus robur L. (De Beer et al. 2003a). This was followed by reports of the fungus from non-native bark beetles infesting Pinus trees (Zhou et al. 2006) and more recently from wounds on native South African trees (Kamgan Nkuekam et al. 2008a). It has also been reported from Uganda (Kamgan Nkuekam et 
al. 2008b) and Tanzania (Grobbelaar et al. 2009). In this study, we collected O. quercus from three Eucalyptus spp. (E. diversicolor, E. saligna, E. grandis) and from logs of various Eucalyptus trees grown in the Soutpansberg and Tzaneen areas (Limpopo Province), Cape Town, George, Stellenbosch (Western Cape Province), Kumbu and Lotebeni (Eastern Cape Province) (Table 1). This finding has expanded the host and geographic ranges of O. quercus in South Africa substantially. It further supports the view that $O$. quercus has a wide host and geographic distribution (Brasier and kirk 1993; Harrington et al. 2001, De Beer et al. 2003a; Kamgan Nkuekam et al. 2008b). It has, however, been suggested that it represents a species complex (Grobbelaar et al. 2008) and this view could change views regarding the host and geographic range of the fungus in the future.

Isolates of $O$. quercus collected from eucalypt trees in this study were found to be genetically diverse, especially in the BT sequence data, where nine haplotypes of the fungus were identified. The ITS and TEF data were more conserved. This trend has emerged in the past from numerous studies considering O. quercus (Grobbelaar et al. 2008, 2009; Kamgan Nkuekam et al. 2010a). It provides further evidence of the fact that this heterothallic fungus reproduces sexually in Southern Africa, and if it is not native to the area it would have been present in the country for a very long period on time.

O. quercus was collected from a wide variety of sites in this study. The fungus was found in the Western Cape Province which has a Mediterranean climate, with hot sunny summers and cold, rainy winters, in Limpopo with a tropical climate, Tzaneen and Mpumalanga with sub-tropical climates, and in the Eastern Cape Province with a temperate climate with year-round rainfall (Fig. 7). The fungus thus seems to be highly adaptive to climatic conditions, which explain why it has a worldwide distribution (Morelet 1992; Brasier and Kirk 1993; Harrrington et al. 2001, De Beer et al. 2003a; Kamgan Nkuekam et al. 2008a, b; Paciura et al. 2010).

Finding $O$. tsotsi in this study was an interesting result. It is a recently erected member of the $O$. piceae complex, closely related to O. quercus. It occurs throughout southern Africa on hardwood trees in countries such as Malawi, Uganda and South Africa (Grobbelaar et al. 2009). In Malawi O. tsotsi occurs on E. grandis and native Julbenardia globiflora (Benth.) Troupin, in Uganda it is known from non-native Acacia mearnsii while in South Africa it occurs on various Eucalyptus species (Grobbelaar et al. 2009). It has recently also been reported from Eucalyptus pulpwood chips in China (Grobbelaar et al. 2010b). In this study, O. tsotsi was found on three Eucalyptus spp. (E. grandis, E. maculata, E. cloeziana) and is reported for the first time from nitidulid beetles. $O$. tsotsi was for many years confused with $O$. quercus based on their cultural resemblance and similar morphology. However, it was recently recognized as a distinct taxon based on genetic studies using polymorphic sequence repeats (Grobbelaar et al. 2008) and multigene 
DNA sequence phylogenies (Grobbelaar et al. 2009). The presence of many haplotypes within the BT and TEF data sets shows that the species is highly variable.

Similar to $O$. quercus, $O$. tsotsi was collected from wide variety of sites in this study. It was found in most areas where O. quercus, a closely related species, was collected (Fig. 7). Recent reports of $O$. tsotsi from Eucalyptus trees in Australia and China, and from agar wood in Vietnam, clearly show that the distribution and host range of the fungus is poorly understood (Paciura et al. 2010; Kamgan Nkuekam et al. 2010a; Grobbelaar et al. 2010b). It has also shown that, like $O$. quercus, $O$. tsotsi could have a global distribution and can survive under wide varieties of climatic conditions.

This study represents the first report of O. tasmaniense on Eucalyptus trees in South Africa. The fungus was first described from eucalypts in Australia (Kamgan Nkuekam et al. 2010b). However, O. tasmaniense appears to prefer a Mediterranean climate. It was found exclusively in the Western Cape Province (Cape Town and Stellenbosch) in South Africa, while in Australia, it originated from numerous localities in Tasmania, which reside in a temperate climatic zone. In Australia O. tasmaniense occurs on E. nitens, E. globulus and E. saligna (Kamgan Nkuekam et al. 2010b), while in South Africa it was found on E. saligna, E. diversicola and it was isolated from nitidulid beetles. It is possible that this fungus is native to Australia where eucalypts are endemic.

This study represents the first reports of $O$. quercus, O. tsotsi and O. tasmaniense from nitidulid beetles. The three fungi were isolated from Brachypeplus depressus, from an unknown Carpophilus species and from Carpophilus humeralis. O. quercus in the northern Hemisphere is vectored by bark beetles in what is considered to be a loose association (Kirisits 2004; Romón et al. 2007). Most recently it was also reported from a Scolytus sp. infesting birch trees in Norway (Linnakoski et al. 2009). The only other report of an Ophiostoma spp. associated with nitidulids beetles is $O$. piceae that was isolated from the surface of seven free-flying nitidulid beetles in the United States of America (Juzwik and French 1983). In the southern Hemisphere, the only report of O. quercus from insects is from non-native bark beetles infesting pine trees in South Africa (Zhou et al. 2001). It was, therefore, not surprising to find $O$. quercus and other closely related Ophiostoma spp. associated with insects such as nitidulid beetles in South Africa. This is an indication that, nitidulid beetles probably spread these fungi in this country.

This study represents the most comprehensive consideration of Ophiostoma and nitidulid beetles infecting Eucalyptus trees in South Africa ever to have been undertaken. The results show that Ophiostoma are diverse on wounds on Eucalyptus spp. in South Africa and they highlight the need for additional studies of this type where other Ophiostoma species are likely to be discovered. Isolating $O$. quercus, O. tasmaniense and $O$. tsotsi from nitidulid beetles collected during the surveys suggests that nitidulid beetles are probably the vectors of these fungi, and it emphasizes the 
value of monitoring these insects and their fungal associates. Of the fungi collected in this study, $O$. quercus, O. tasmaniense and $O$. tsotsi have been reported from trees in countries other than South Africa. This suggests intercontinental movement of these fungi, most likely through infected plant material and insects often associated with them.

Acknowledgements We thank the DST/NRF Center of Excellence in Tree Health Biotechnology (CTHB), National Research Foundation of South Africa (NRF), the THRIP Initiative of the Department of Trade and Industry (THRIP/DST), members of the Tree Protection Co-operative Programme (TPCP) and the University of Pretoria for funding and the facilities to undertake this study. Dr. Andrew Cline from the USA is thanked for assisting us with the identification of insects collected in this study. We further thank Dr. Hugh Glen who provided the Latin diagnoses and made suggestions for the names of the new taxa. Samples from Zambia were collected through a NRF research grant to Prof. J. Roux and Dr. Muimba A. Kankolongo of the Copperbelt University, Kitwe, Zambia.

\section{References}

Aghayeva DN, Wingfield MJ, De Beer ZW, Kirisits T (2004) Two new Ophiostoma species with Sporothrix anamorphs from Austria and Azerbaijan. Mycologia 96: 866-878.

Aghayeva DN, Wingfield MJ, Kirisits T, Wingfield BD (2005) Ophiostoma dentifundum sp. nov. from oak in Europe, characterized using molecular phylogenetic data and morphology. Mycol Res 109: 1127-1136.

Anonymous 2008. Eucalyptus online book \& newsletter, Number 16. (www.eucalyptus.com.br/newsseng_ag08.html).

Brasier CM (2000). Intercontinental spread and continuing evolution of the Dutch elm disease pathogens. In: Dunn CP (eds) The elms: breeding, conservation and disease management. Kluwer Academic Publishers, Boston USA, Dordrecht The Netherlands, London UK, PP. 61-72.

Brasier CM, Kirk SA (1993) Sibling species within Ophiostoma piceae. Mycol Res 97: 811-816.

Bridges JR, Moser JC (1986) Relationship of phoretic mites (Acari: Tarsonemidae) to the bluestaining fungus, Ceratocystis minor, in tree infested by southern pine beetle (Coleoptera, Scolytidae). Environ Entomol 15: 951-953.

Chung WH, Kim J, Yamaoka Y, Uzunovic A, Masuya H, Breuil C (2006) Ophiostoma breviusculum sp. nov. (Ophiostomatales, Ascomycota) is a new species in the Ophiostoma piceae complex associated with bark beetles in infesting larch in Japan. Mycologia 98: 801814.

Cobb FW (Jr.) (1988) Leptographium wageneri, cause of black-stain root disease: A review of its discovery, occurrence and biology with emphasis on pinyon and ponderosa pine. In: Leptographium root diseases on conifers, American Phytopathological Society Press, St. Paul, Minnesota, USA, PP. 41-62.

Crane JL, Schoknecht JD (1973) Conidiogenesis in Ceratocystis ulmi, Ceratocystis piceae and Graphium penicillioides. Am J Bot 60: 346-354.

De Beer ZW, Wingfield BD, Wingfield MJ (2003a) The Ophiostoma piceae-complex in the Southern Hemisphere: a phylogenetic study. Mycol Res 107: 469-476.

De Beer ZW, Harrington TC, Vismer HF, Wingfield BD, Wingfield MJ (2003b) Phylogeny of the Ophiostoma stenoceras-Sporothrix schenckii complex. Mycologia 95: 434-441. 
De Beer ZW, Wingfield MJ (2006) Emerging lineages, genera and Ecological patterns in the Ophiostomatales. In: Ophiostomatoid fungi: Expanding frontiers, 16-18 August 2006, North Stradbroke Island Brisbane, Australia, Abstract PP. 17.

De Hoog GS (1974) The genera Blastobotrys, Sporothrix, Calcarisporium and Calcarisporiella gen. nov. Stud Mycol 7: 1-84.

De Meyer EM, De Beer ZW, Summerbell RC, Moharram AM, De Hoog GS, Vismer HF, Wingfield MJ (2008) Taxonomy and phylogeny of new wood- and soil-inhabiting Sporothrix species in the Ophiostoma stenoceras-Sporothrix schenckii complex. Mycologia 100: 647-661.

Fergusson NDM (1982) Pooter post. Antenna 6: 282-284.

Findlay GH (1970) The epidemiology of sporotrichosis in the Transvaal. Sabouraudia 7: 231-236.

Gibbs JN (1978) Intercontinental epidemiology of Dutch elm disease. Ann Rev Phytopath 16: 287307.

Glass NL, Donaldson GC (1995) Development of primer sets designed for use with the PCR to amplify conserved genes from filamentous Ascomycetes. Appl Environ Microbiol 61: 13231330.

Grobbelaar JW, Aghayeva D, De Beer ZW, Bloomer P, Wingfield MJ, Wingfield BD (2009) Delimitation of Ophiostoma quercus and its synonyms using multiple gene phylogenies. Mycol Progress 8: 221-236.

Grobbelaar JW, Barnes I, Cortinas M-N, Bloomer P, Wingfield MJ, Wingfield BD (2008) Development and characterization of polymorphic markers for the sap stain fungus Ophiostoma quercus. Mol Ecol Res 9: 399-401.

Grobbelaar JW, De Beer ZW, Bloomer P, Wingfield MJ, Wingfield BD (2010a) Ophiostoma tsotsi sp. nov., a wound-infesting fungus of hardwood trees in Africa. Mycopathologia 169: 413423.

Grobbelaar JW, De Beer ZW, Bloomer P, Wingfield MJ, Zhou XD, Wingfield BD (2010b) Discovery of Ophiostoma tsotsi on Eucalyptus wood chips in China. Mycoscience (In press).

Guindon S, Gascuel O (2003) A simple, fast, and accurate algorithm to estimate large phylogenies by maximum likelihood. System Biol 52: 696-704.

Halmschlager E, Messner R, Kowalski T, Prillinger H (1994) Differentiation of Ophiostoma piceae and Ophiostoma quercus by morphology and RADP analysis. System Appl Microbiol 17: 554-562.

Harrington TC. 1993. Diseases of Conifers caused by species of Ophiostoma and Leptographium. In: Wingfield MJ, Seifert KA, Webber JF (eds) Ceratocystis and Ophiostoma: Taxonomy, Ecology, and Pathogenicity. American Phytopathological Society Press, St. Paul, Minnesota, USA, PP. 161-172.

Harrington TC, McNew D, Steimel J, Hofstra D, Farrell R (2001) Phylogeny and taxonomy of the Ophiostoma piceae complex and the Dutch elm disease fungi. Mycologia 93: 111-136.

Heath RN, Van Wyk M, Roux J, Wingfield MJ (2009) Insect associates of Ceratocystis albifundus and patterns of association in a native savanna ecosystem in South Africa. Environ Entomol 38 (2): 356-364.

Huelsenbeck JP, Ronquist F (2001) MRBAYES: Bayesian inference of phylogenetic trees. Bioinformatics 17: 754.

Jacobs K, Wingfield MJ (2001) Leptographium species. Tree pathogens, insect associates and agents of blue stain. American Phytopathological Society Press, St. Paul, Minnesota, USA.

Jacobs K, Kirisits T (2003) Ophiostoma kryptum sp. nov. from Larix deciduas and Picea abies in Europe, similar to O. minus. Mycol Res 107: 1231-1242.

Jacobs K, Bergdahl DR, Wingfield MJ, Halik S, Seifert KA, Bright DE, Wingfield BD (2004) Leptographium wingfieldii introduced into North America and found associated with exotic Tomicus piniperda and native bark beetles. Mycol Res 108: 411-418.

Juzwik J, French DW (1983) Ceratocystis fagacearum and C. piceae on the surfaces of free-flying and fungus-mat-inhabiting nitidulids. Phytopathology 73: 1164-1168. 
Kamgan Nkuekam G, Jacobs K, De Beer ZW, Wingfield MJ, Roux J (2008a) Ceratocystis and Ophiostoma species including three new taxa, associated with wounds on native South African trees. Fungal Divers 29: 37-59.

Kamgan Nkuekam G, Jacobs K, De Beer ZW, Wingfield MJ, Roux J (2008b) Pesotum australiae sp. nov. and Ophiostoma quercus associated with Acacia mearnsii trees in Australia and Uganda. Australas Plant Pathol 37: 406-416.

Kamgan Nkuekam G, Solheim H, De Beer ZW, Jacobs K, Grobbelaar JW, Wingfield MJ, Roux J (2010a) Ophiostoma species, including Ophiostoma borealis sp. nov., infecting wounds of native broad-leaved trees in Norway. Cryptogamie Mycol 31(3): 285-303.

Kamgan Nkuekam G, De Beer ZW, Wingfield MJ, Roux J (2010b) Ophiostoma species (Ophiostomatales, Ascomycota), including two new taxa on eucalypts in Australia. Austral J Bot (in press).

Katoh K, Toh H (2008) Recent developments in the MAFFT multiple sequence alignment program. Brief Bioinform 9: 286-298.

Kirisits T (2004) Fungal associates of European bark beetles with special emphasis on the ophiostomatoid fungi. In: Lieutier F, Day KR, Battistis A, Gregoire JC, Evans HF (eds) Bark and wood boring insects in living trees in Europe, a synthesis. Kluwer Academic Press, The Netherlands, PP. 181-235.

Lawes, MJ., Eeley, HAC., Shackleton, C.M. and Geach, BGS (2004) Indigenous Forests and Woodlands in South Africa. University of KwaZulu-Natal Press.

Linnakoski R, De Beer ZW, Rousi M, Solheim H, Wingfield MJ (2009) Ophiostoma denticiliatum sp. nov. and other Ophiostoma species associated with the birch bark beetle in southern Norway. Persoonia 23: 9-15.

Madrid H, Gene J, Cano J, Silvera C, Guarro J (2010) Sporothrix brunneoviolacea and Sporothrix dimorphospora, two new members of the Ophiostoma stenoceras-Sporothrix schenckii complex. Mycologia 102: 1193-1203.

Malloch D, Blackwell M (1993) Dispersal biology of the ophiostomatoid fungi. In: Wingfield MJ, Seifert KA, Webber JF (eds) Ceratocystis and Ophiostoma: Taxonomy, Ecology, and Patogenicity. American Phytopathological Society Press, St. Paul, PP. 195-206.

Marimon R, Cano J, Gene J, Sutton DA, Kawasaki M, Guarro J (2007) Sporothrix brasiliensis, S. globosa, and S. mexicana, three new Sporothrix species of clinical interest. J Clin Microbiol 45: 3198-3206.

Marimon R, Gene' J, Cano J, Guarro J (2008) Sporothrix luriei: a rare fungus from clinical origin. Med Mycol 46: 621-625.

Mathiesen-Käärik A (1953) Eine Übersicht über die gewöhnlichsten mit Borkenkäfern assoziierten Bläuepilze in Schweden und einige für Schweden neue Bläuepilze. Meddelanden från Statens Skogsforskningsinstitut 43: 1-74.

Moller WJ, Devay JE (1968) Insect transmission of Ceratocystis fimbriata in deciduous fruit orchards. Phytopathology 58: 1499-1507.

Morelet M (1992) Ophiostoma querci sur chene en France. Ann Soc Sci Nat Archeol Toulon 44: 106-112.

Moser JC (1997) Phoretic mites and their hyperphoretic fungi associated with flying Ips typographus, Japonicus Niijima (Col., Scolytidae) in Japan. J Appl Entomol 121: 425-428.

O'Donnell K, Cigelnik E (1997) Two divergent intragenomic rDNA ITS2 types within a monophyletic lineage of the fungus Fusarium are nonorthologous. Mol Phylogenet Evol 7: 103-116.

Paine TD, Raffa KF, Harrington TC (1997) Interactions among Scolytid bark beetles, their associated fungi, and live host conifers. Ann Rev Entomol 42: 179-206.

Paciura D, Zhou XD, De Beer ZW, Jacobs K, Wingfield MJ (2010) Characterization of synnematous bark beetle-associated fungi from china, including Graphium carbonarium sp. nov. Fungal Divers 40: 75-88. 
Posada D, Crandall KA (1998) MODELTEST: testing the model of DNA substitution.

Bioinformatics 14: 817-818.

Przybyl K, De Hoog GS (1989) On the variability of Ophiostoma piceae. Anton van leeuwenhoek 55: 177-188.

Rayner RW (1970) A mycological colour chart. Commonwealth Mycological Institute and British Mycological Society, Kew, Surrey.

Roets F, Beer ZW de, Dreyer LL, Zipfel R, Crous PW, Wingfield MJ (2006) Multigene phylogeny for Ophiostoma spp. reveals two new species from Protea infructescences. Stud Mycol 55: 199-212.

Roets F, Crous PW, Wingfield MJ, Dreyer LL (2007) Discovery of fungus-mitemutualism within a unique niche of the Cape Floral Kingdom. Environl Entomol 36: 1226-1237.

Roets F, De Beer ZW, Wingfield MJ, Crous PW, Dreyer LL (2008) Ophiostoma gemellus and Sporothrix variecibatus from mites infesting Protea infructescences in South Africa. Mycologia 100: 496-510.

Roets F, Dreyer LL, Crous PW, Wingfield MJ (2009) Mite-mediated hyperphoretic dispersal of Ophiostoma spp. from the infructescences of South African Protea spp. Environ Entomol 38: 143-152.

Roets F, Wingfield BD, De Beer ZW, Wingfield MJ, Dreyer LL (2010) Two new Ophiostoma species from Protea caffra in Zambia. Persoonia 24: 18-28.

Romón P, Zhou X, Iturrondobeitia JC, Wingfield MJ, Goldarazena A (2007) Ophiostoma species (Ascomycetes, Ophiostomatales) associated with bark beetles (Coleoptera, Scolytinae) colonizing Pinus radiata in northern Spain. Can J Microbiol 53: 756-767.

Seifert KA (1993) Sapstain of commercial lumber by species of Ophiostoma and Ceratocystis. In: Wingfield MJ, Seifert KA, Webber JF (eds) Ceratocystis and Ophiostoma: Taxonomy, Ecology, and Patogenicity. American Phytopathological Society, St. Paul Minnesota, USA, PP. 141-151.

Six DL (2003) Bark beetle fungus symbiosis. In: Bourtzis K, Miller TA, eds. Insect symbiosis. CRC Press, New York, P. 97-114.

Swofford DL (1998) PAUP. Phylogenetic analysis using parsimony (and other methods), Version 4, Sinaur Associates, Sunderland, Massachusetts.

Tamura K, Dudley J, Nei M, Kumar S (2007) MEGA4: Molecular Evolutionary Genetics Analysis (MEGA) software version 4.0. Mol Biol Evol 24: 1596-1599.

Whitney HS (1982) Relationships between bark beetles and symbiotic organism. In: Mitton JB, Sturgeon KB (eds) Bark beetles in North American conifers. A system for the study of evolutionary biology. University of Texas Press, Austin, Texas, PP. 183-211.

White TJ, Bruns T, Lee S, Taylor J (1990) Amplification and direct sequencing of fungal ribosomal RNA genes for phylogenetics. In: Innis MA, Gelfand DH, Sninsky JJ, White TJ (eds) PCR Protocols: A sequencing guide to methods and applications. Academic Press, San Diego, P. 315-322.

Wingfield MJ, Kendrick B, Schalk Van Wyk SP (1991) Analysis of conidium ontogeny in anamorphs of Ophiostoma: Pesotum and Phialographium are synonyms of Graphium. Mycol Res 95: 1328-1333.

Wingfield MJ, Seifert KA, Webber JF (1993) Ceratocystis and Ophiostoma: Taxonomy, Ecology and Pathogenicity. American Phytopathological Society Press, St. Paul, Minnesota, USA.

Zipfel RD, De Beer ZW, Jacobs K, Wingfield MJ, Wingfield BD (2006) Multigene phylogenies define Ceratocystiopsis and Grosmannia distinct from Ophiostoma. Stud Mycol 55: 75-97.

Zhou XD, De Beer ZW, Wingfield MJ (2006) DNA sequence comparisons of Ophiostoma spp., including Ophiostoma aurorae sp. nov., associated with pine bark beetles in South Africa. Stud Mycol 55: 269-277.

Zhou XD, De Beer ZW, Wingfield BD, Wingfield MJ (2001) Ophiostomatoid fungi associated with three pine-infesting bark beetles in South Africa. Sydowia 53: 290-300. 
Table 1: Geographic distribution, host ranged and Genbank accession numbers for sequences of Ophiostoma isolates collected in this study and haplotypes of beta tubulin dataset of the $O$. piceae complex.

\begin{tabular}{|c|c|c|c|c|c|c|c|}
\hline \multirow[t]{2}{*}{ Species } & \multirow[t]{2}{*}{$\mathbf{C M W}^{1}$} & \multirow[t]{2}{*}{ Host/Insect } & \multirow[t]{2}{*}{ Origin $^{2}$} & ITS & \multicolumn{2}{|l|}{$\overline{\text { BT }}$} & \multirow{2}{*}{$\begin{array}{l}\text { EF } \\
\text { Acc. no. }\end{array}$} \\
\hline & & & & Acc. no. & Haplotypes $^{3}$ & Acc. no. & \\
\hline \multirow[t]{9}{*}{ O. candidum sp. nov. } & 26482 & E. cloeziana & Soutpansberg, LIM & NA & $\mathrm{X}$ & NA & NA \\
\hline & 26483 & $"$ & " & HM051408 & $\mathrm{X}$ & HM041873 & $"$ \\
\hline & 26484 & $"$ & $"$ & HM051409 & $\mathrm{X}$ & HM041874 & $"$ \\
\hline & 26485 & $"$ & $"$ & HM051410 & $\mathrm{X}$ & HM041871 & $"$ \\
\hline & 26486 & $"$ & $"$ & HM051411 & $\mathrm{X}$ & HM041872 & $"$ \\
\hline & 26487 & $"$ & $"$ & NA & $\mathrm{X}$ & NA & $"$ \\
\hline & 26488 & $"$ & $"$ & $"$ & $\mathrm{X}$ & $"$ & $"$ \\
\hline & 26489 & $"$ & $"$ & $"$ & $\mathrm{X}$ & $"$ & $"$ \\
\hline & 26817 & $"$ & $"$ & $"$ & $\mathrm{X}$ & $"$ & $"$ \\
\hline \multirow[t]{8}{*}{ O. fumeum sp. nov. } & 26813 & Eucalyptus spp. & $"$ & HM051412 & $\mathrm{Y}$ & HM041878 & $"$ \\
\hline & 26814 & $"$ & $"$ & HМ051413 & $\mathrm{Y}$ & HM041875 & $"$ \\
\hline & 26815 & $"$ & $"$ & NA & $\mathrm{Y}$ & NA & $"$ \\
\hline & 26816 & $"$ & $"$ & HМ051414 & $\mathrm{Y}$ & HM041876 & $"$ \\
\hline & 26818 & $"$ & Zambia & HM051415 & $\mathrm{Y}$ & HM041877 & $"$ \\
\hline & 26819 & $"$ & $"$ & NA & $\mathrm{Y}$ & NA & " \\
\hline & 26820 & $"$ & $"$ & NA & $\mathrm{Y}$ & NA & " \\
\hline & 26822 & $"$ & $"$ & NA & $\mathrm{Y}$ & NA & $"$ \\
\hline \multirow[t]{13}{*}{ O. quercus } & 25020 & E. grandis & Tzaneen, LIM & NA & $\mathrm{A}$ & NA & $"$ \\
\hline & 27057 & Eucalyptus spp. & George, WC & NA & F & NA & $"$ \\
\hline & 27058 & $"$ & $"$ & HМ051398 & $\mathrm{J}$ & HM041859 & $"$ \\
\hline & 27059 & $"$ & $"$ & NA & B & NA & $"$ \\
\hline & 27060 & $"$ & $"$ & NA & $\mathrm{H}$ & NA & $"$ \\
\hline & 27062 & $"$ & $"$ & NA & $\mathrm{J}$ & NA & $"$ \\
\hline & 27064 & $"$ & $"$ & NA & $\mathrm{F}$ & NA & $"$ \\
\hline & 27071 & $"$ & $"$ & NA & $\mathrm{F}$ & NA & $"$ \\
\hline & 27072 & $"$ & $"$ & NA & $\mathrm{H}$ & NA & $"$ \\
\hline & 27073 & $"$ & $"$ & NA & $\mathrm{G}$ & NA & $"$ \\
\hline & 27074 & $"$ & $"$ & NA & $\mathrm{H}$ & NA & $"$ \\
\hline & 27075 & $"$ & $"$ & NA & $\mathrm{F}$ & NA & $"$ \\
\hline & 27076 & $"$ & $"$ & NA & I & NA & $"$ \\
\hline
\end{tabular}




\begin{tabular}{|c|c|c|c|c|c|c|}
\hline 27077 & $"$ & $"$ & NA & I & NA & " \\
\hline 27078 & E. diversicolor & Cape Town, WC & NA & A & NA & " \\
\hline 27089 & $"$ & $"$ & NA & A & NA & $"$ \\
\hline 27145 & E. saligna & $"$ & NA & B & NA & $"$ \\
\hline 27147 & Eucalyptus spp. & George, WC & NA & $\mathrm{F}$ & NA & $"$ \\
\hline 27150 & $"$ & $"$ & HM051405 & G & HM041865 & $"$ \\
\hline 27152 & $"$ & $"$ & HМ051404 & $\mathrm{C}$ & HM041860 & HM041895 \\
\hline 27164 & Eucalyptus logs & Stellenbosch, WC & HM051403 & $\mathrm{F}$ & HM041864 & HM041894 \\
\hline 27165 & $"$ & $"$ & NA & A & NA & NA \\
\hline 27168 & E. grandis & Kumbu, EC & $"$ & A & $"$ & " \\
\hline 27169 & $"$ & $"$ & $"$ & B & $"$ & $"$ \\
\hline 27170 & $"$ & $"$ & $"$ & $\mathrm{~A}$ & $"$ & $"$ \\
\hline 27171 & $"$ & $"$ & $"$ & $\mathrm{~B}$ & $"$ & $"$ \\
\hline 27172 & $"$ & $"$ & $"$ & B & $"$ & $"$ \\
\hline 27173 & $"$ & $"$ & HM051397 & $\mathrm{H}$ & HM041856 & HM041897 \\
\hline 27174 & $"$ & $"$ & NA & $\mathrm{B}$ & NA & NA \\
\hline 27191 & E. diversicolor & Cape Town, WC & " & A & $"$ & $"$ \\
\hline 27192 & $"$ & $"$ & HМ051399 & A & HM041858 & HM041893 \\
\hline 28196 & Eucalyptus spp. & George, WC & NA & $\mathrm{H}$ & NA & NA \\
\hline 28201 & Eucalyptus logs & Cape Town, WC & HM051400 & $\mathrm{H}$ & HM041857 & HM041892 \\
\hline 28212 & E. grandis & Lotebeni, EC & NA & B & NA & NA \\
\hline 28213 & $"$ & $"$ & $"$ & $\mathrm{~B}$ & $"$ & $"$ \\
\hline 28214 & $"$ & $"$ & " & A & $"$ & $"$ \\
\hline 28215 & $"$ & $"$ & HM051402 & $\mathrm{E}$ & HM041863 & HM041891 \\
\hline 28216 & $"$ & $"$ & NA & $\mathrm{B}$ & NA & NA \\
\hline 29693 & Carpophilus sp. & Cape Town, WC & $"$ & A & $"$ & $"$ \\
\hline 29717 & B. depressus & $"$ & $"$ & A & $"$ & $"$ \\
\hline 29734 & $"$ & Kumbu, EC & HM051407 & $\mathrm{D}$ & HM041862 & HM041896 \\
\hline 29736 & $"$ & $"$ & NA & A & NA & NA \\
\hline 29738 & $"$ & $"$ & " & A & $"$ & $"$ \\
\hline 29824 & $"$ & $"$ & " & B & $"$ & $"$ \\
\hline 29827 & $"$ & Stellenbosch, WC & $"$ & $\mathrm{~F}$ & $"$ & $"$ \\
\hline 29832 & $"$ & $"$ & $"$ & A & $"$ & $"$ \\
\hline 30863 & E. saligna & Soutpansberg, LIM & $"$ & B & " & " \\
\hline
\end{tabular}




\begin{tabular}{|c|c|c|c|c|c|c|c|}
\hline & 30864 & $"$ & $"$ & HM051406 & B & HM041861 & HM041890 \\
\hline & 30865 & $"$ & $"$ & NA & $\mathrm{B}$ & NA & NA \\
\hline & 30868 & E. grandis & Sabie, MP & $"$ & A & $"$ & $"$ \\
\hline & 30869 & $"$ & $"$ & $"$ & $\mathrm{~A}$ & $"$ & $"$ \\
\hline \multirow[t]{12}{*}{ O. tasmaniense } & 27090 & E. diversicolor & Cape Town, WC & $"$ & $\mathrm{~L}$ & $"$ & $"$ \\
\hline & 27146 & E. saligna & $"$ & HМ051391 & M & HM041849 & $"$ \\
\hline & 27161 & E. diversicolor & $"$ & HM051392 & $\mathrm{K}$ & HM041850 & HM041886 \\
\hline & 27189 & $"$ & $"$ & NA & $\mathrm{K}$ & NA & NA \\
\hline & 27190 & $"$ & $"$ & $"$ & $\mathrm{~K}$ & $"$ & $"$ \\
\hline & 27193 & $"$ & $"$ & HM051396 & $\mathrm{L}$ & HМ041853 & $"$ \\
\hline & 27195 & $"$ & $"$ & HМ051393 & $\mathrm{K}$ & HM041851 & HM041887 \\
\hline & 29685 & Carpophilus sp. & $"$ & NA & $\mathrm{K}$ & NA & NA \\
\hline & 29688 & $"$ & $"$ & HM051395 & $\mathrm{K}$ & HM041852 & HM041888 \\
\hline & 29691 & $"$ & $"$ & NA & $\mathrm{K}$ & NA & NA \\
\hline & 29712 & B. depressus & $"$ & HМ051401 & $\mathrm{L}$ & HM041855 & HM041889 \\
\hline & 29831 & $"$ & Stellenbosch, WC & HM051394 & $\mathrm{L}$ & HM041854 & HM041885 \\
\hline \multirow[t]{18}{*}{ O. tsotsi } & 24954 & Eucalyptus spp. & Pietermartzburg, KZN & NA & 2 & NA & NA \\
\hline & 24956 & $"$ & $"$ & $"$ & 1 & $"$ & $"$ \\
\hline & 24959 & $"$ & $"$ & $"$ & 1 & $"$ & $"$ \\
\hline & 24964 & $"$ & $"$ & $"$ & 5 & $"$ & $"$ \\
\hline & 24966 & $"$ & $"$ & $"$ & 1 & $"$ & $"$ \\
\hline & 24968 & $"$ & $"$ & $"$ & 1 & $"$ & $"$ \\
\hline & 24971 & $"$ & $"$ & $"$ & 1 & $"$ & $"$ \\
\hline & 24977 & $"$ & Kwambonambi, KZN & $"$ & 1 & $"$ & $"$ \\
\hline & 24978 & $"$ & $"$ & $"$ & 5 & $"$ & $"$ \\
\hline & 24981 & $"$ & $"$ & $"$ & 6 & $"$ & $"$ \\
\hline & 24982 & $"$ & $"$ & HM051390 & 3 & HM041845 & HM041882 \\
\hline & 24983 & $"$ & $"$ & HM051388 & 5 & HM041847 & HM041880 \\
\hline & 24985 & $"$ & $"$ & NA & 1 & NA & NA \\
\hline & 24986 & E. grandis & Tzaneen, LIM & HM051385 & 4 & HM041848 & HM041879 \\
\hline & 24987 & $"$ & $"$ & NA & 2 & NA & NA \\
\hline & 24988 & $"$ & $"$ & HM051387 & 2 & HM041846 & HМ041883 \\
\hline & 24990 & $"$ & $"$ & NA & 5 & NA & NA \\
\hline & 24992 & $"$ & $"$ & $"$ & 1 & $"$ & $"$ \\
\hline
\end{tabular}




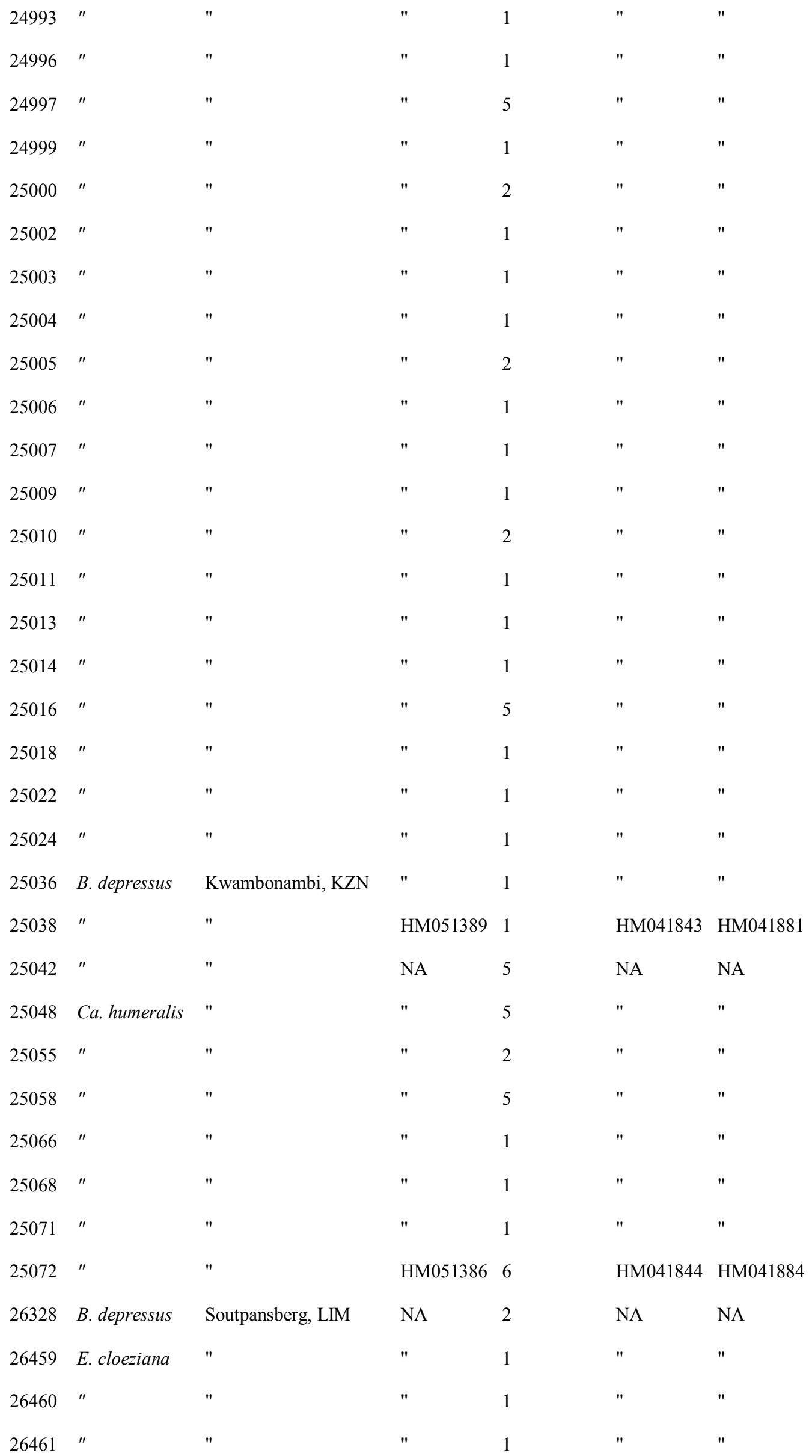




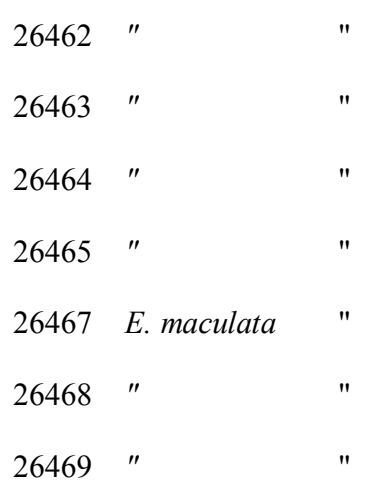

$$
\begin{aligned}
& \hline \text { EC }=\text { Eastern Cape } \\
& \text { WC }=\text { Western Cape } \\
& \text { LIM }=\text { Limpopo } \\
& \text { KZN = KwaZulu Natal } \\
& \mathrm{MP}=\text { Mpumalanga } \\
& \mathrm{SA}=\text { South Africa } \\
& \mathrm{ZAM}=\text { Zambia } \\
& \mathrm{UK}=\text { United Kingdom } \\
& \mathrm{NZ}=\text { New-Zealand }
\end{aligned}
$$


Fig. 1 Phylogram obtained from maximum likelihood analyses of DNA sequences data from part of BT gene region, showing the relationship between members of Ophiostoma piceae complex from eucalypt trees in South Africa and other Ophiostoma reference strains. Isolates sequenced in this study are in bold font type. MP bootstrap values, Bayesian posterior probabilities and ML bootstrap values respectively are indicated at each relevant node.

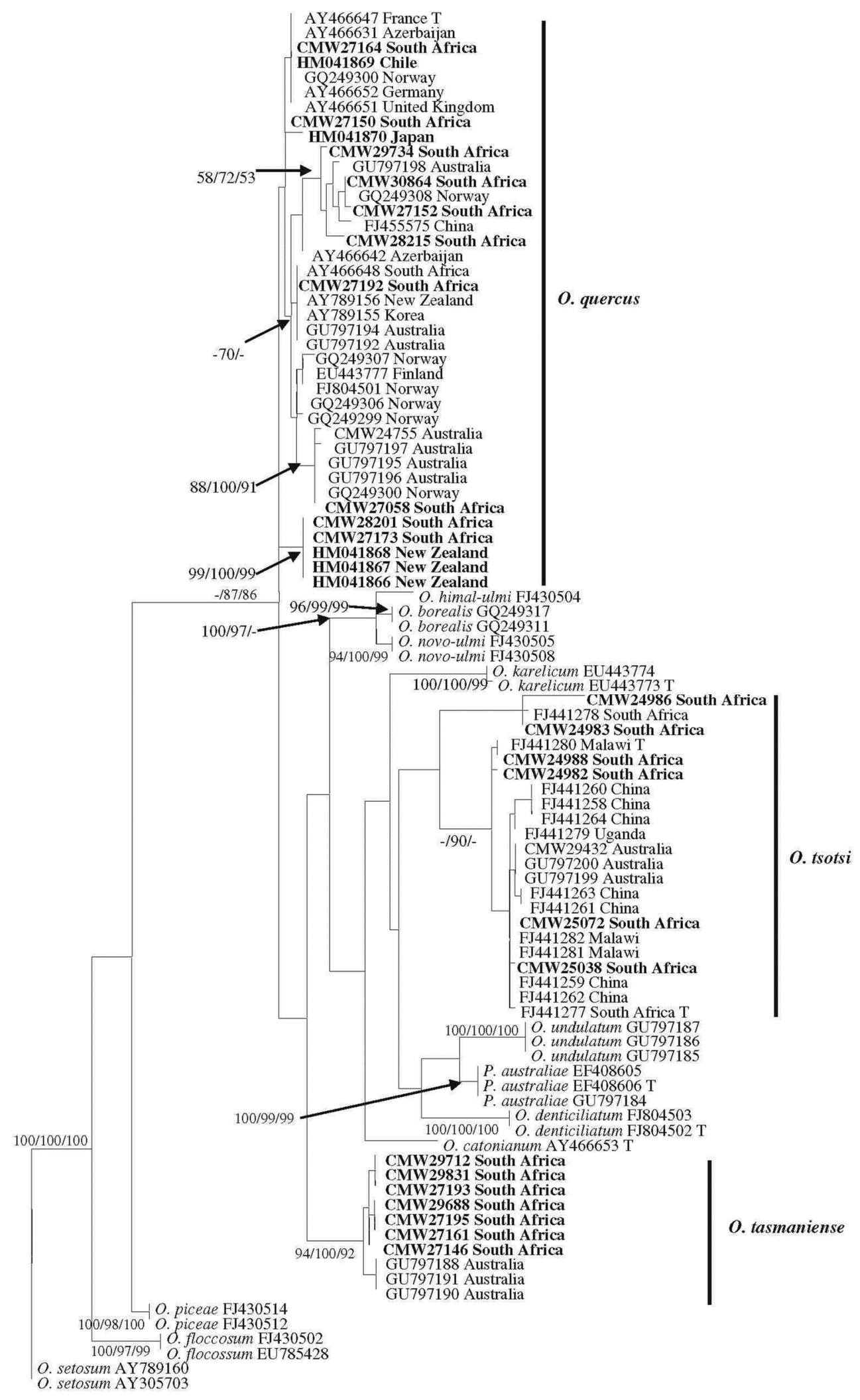


Fig. 2 Phylogram obtained from maximum likelihood analyses of DNA sequences data from part of BT gene region, showing the relationship between $O$. fumeum, $O$. candidum from eucalypt trees in South Africa and other members of Ophiostoma stenoceras reference strains. Isolates sequenced in this study are in bold type. MP bootstrap values, Bayesian posterior probabilities and ML bootstrap values respectively are indicated at each relevant node.

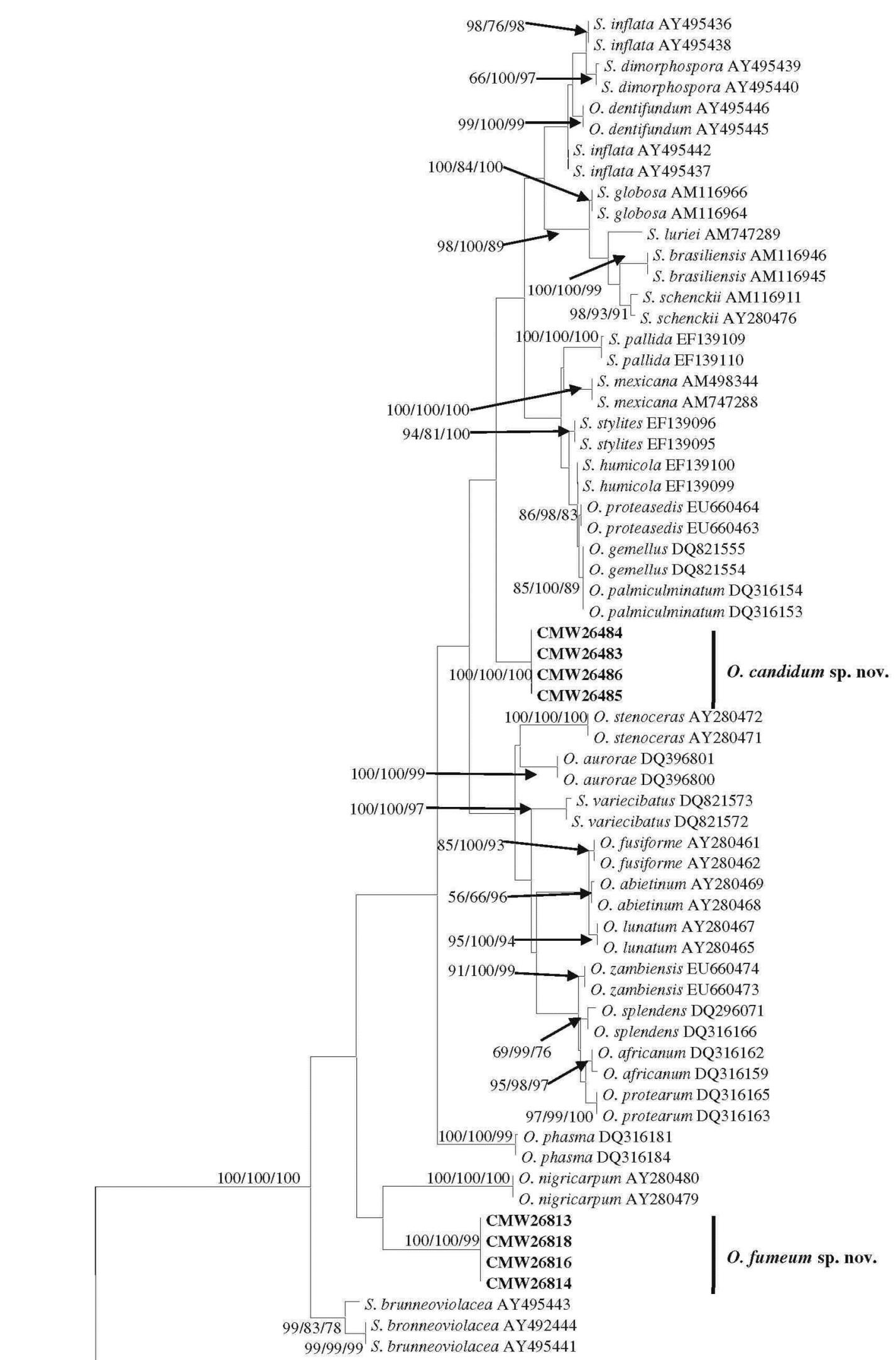


Fig. 3 Phylogram obtained from maximum likelihood analyses of DNA sequences of the TEF gene region, showing the relationship between members of Ophiostoma piceae complex from eucalypt trees in South Africa and other Ophiostoma reference strains. Isolates sequenced in this study are in bold font type. MP bootstrap values, Bayesian posterior probabilities and ML bootstrap values respectively are indicated at each relevant node.

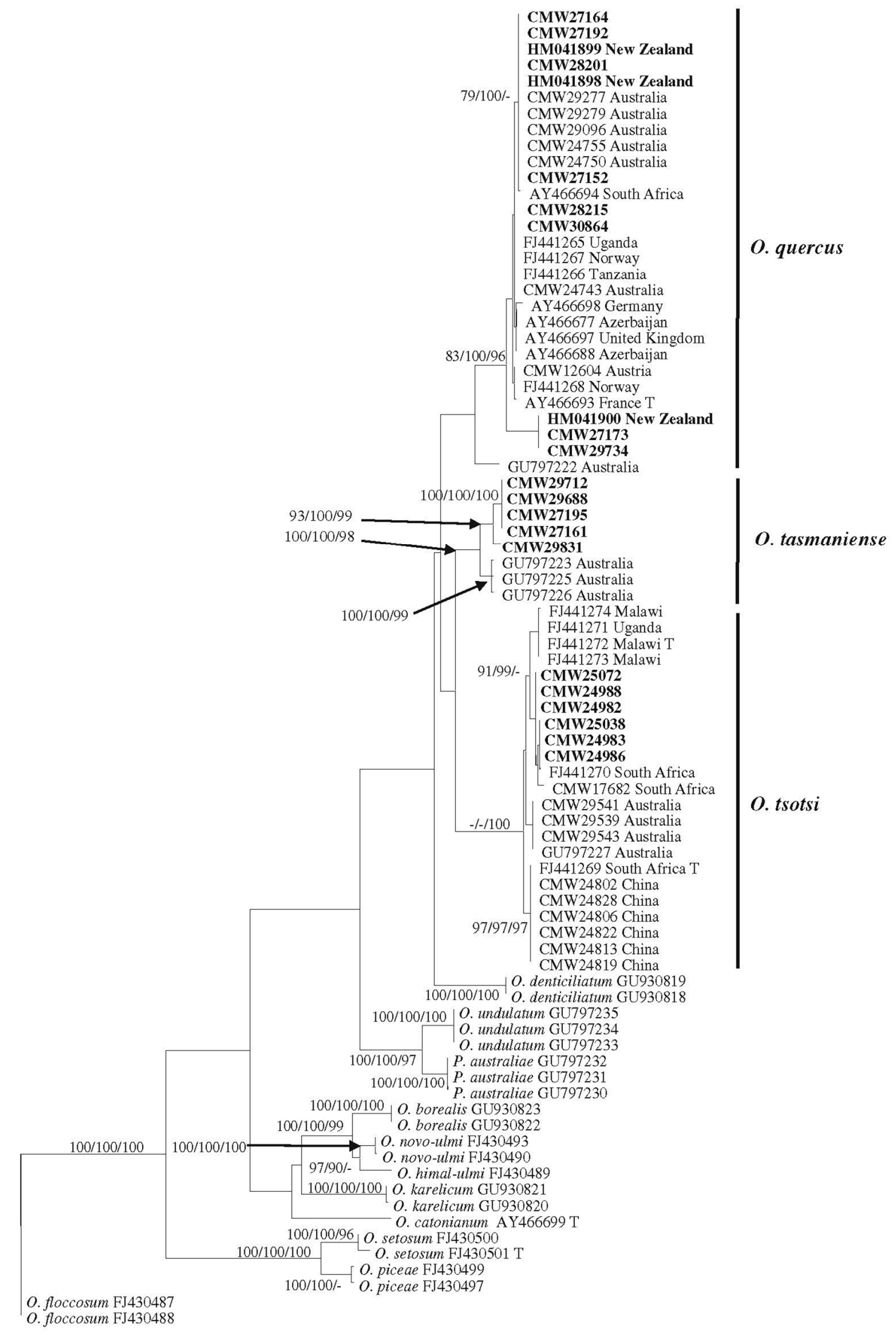


Fig. 4 Phylogram obtained from maximum likelihood analyses of DNA sequences of the ITS gene region, showing the relationship between Ophiostoma species from Eucalyptus trees in South Africa and other Ophiostoma reference strains. Isolates sequenced in this study are in bold type. MP bootstrap values, Bayesian posterior probabilities and ML bootstrap values respectively are indicated at each relevant node.

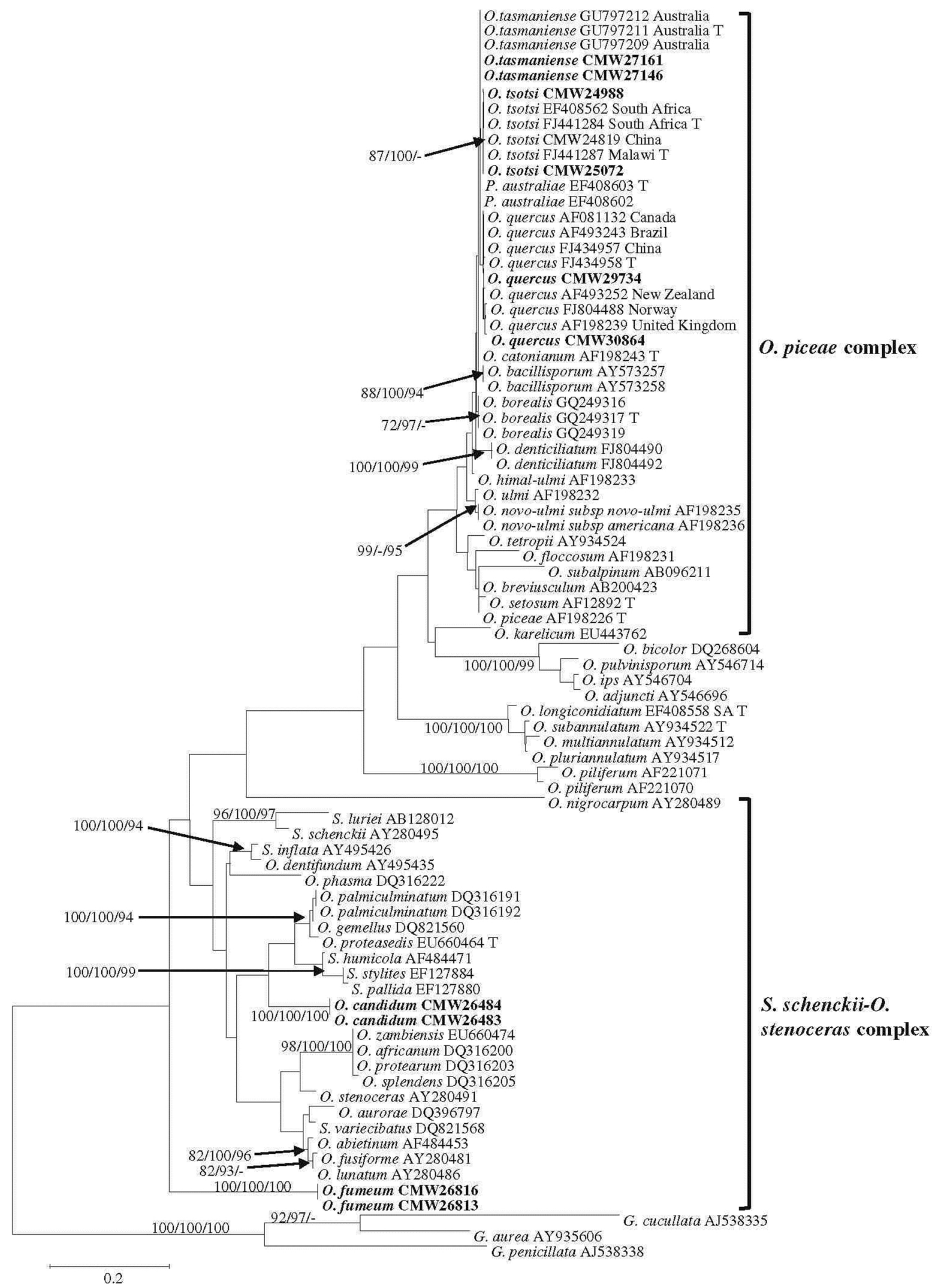


Fig. 5 Morphological characteristics of Ophiostoma candidum sp. nov. A) Globose ascomatal base (scale bar = $50 \mu \mathrm{m}), \mathrm{B}$ ) divergent ostiolar hyphae (scale bar $=20 \mu \mathrm{m}$ ), C) Reniform ascospores (scale bar $=10 \mu \mathrm{m}$ ), D) Sporothrix conidiogenous cell with denticles visible on tip of conidiogenous cell (scale bar $=10 \mu \mathrm{m}), \mathrm{E}$ ) Oblong to curved conidia (scale bar $=1 \mu \mathrm{m})$.

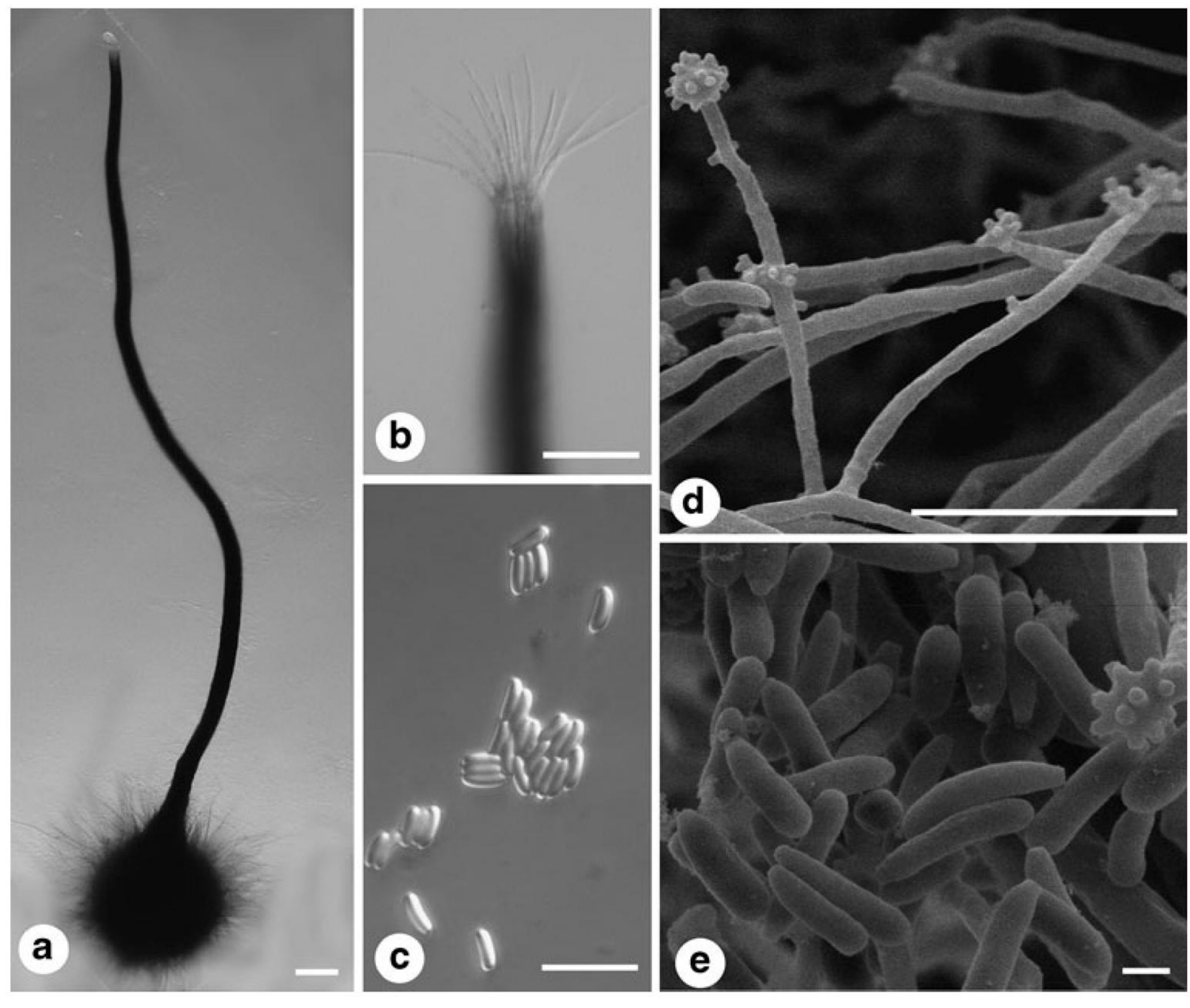


Fig. 6 Morphological characteristics of Ophiostoma fumeum sp. nov. A) Globose ascomatal base (scale bar $=20 \mu \mathrm{m}$ ), B) Allantoid ascospores (scale bar $=10 \mu \mathrm{m})$, C) Oblong conidia (scale bar $=10 \mu \mathrm{m})$, D) Sporothrix conidiogenous cell with denticles visible on tip of conidiogenous cell (scale bar $=10 \mu \mathrm{m})$,
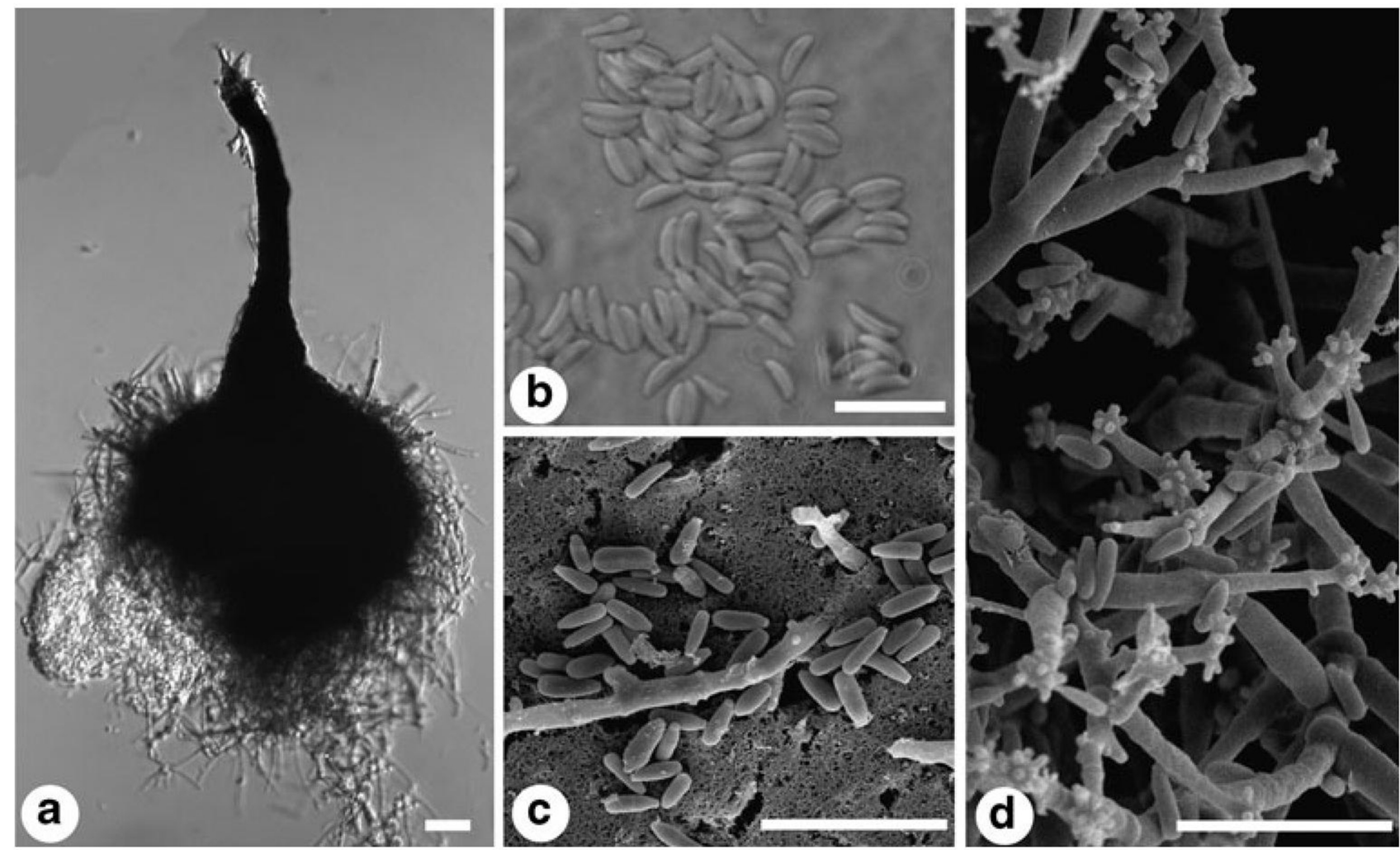
Fig. 7 Map of South Africa showing the current geographic distribution of Ophiostomatalean fungi on eucalypt in the country.

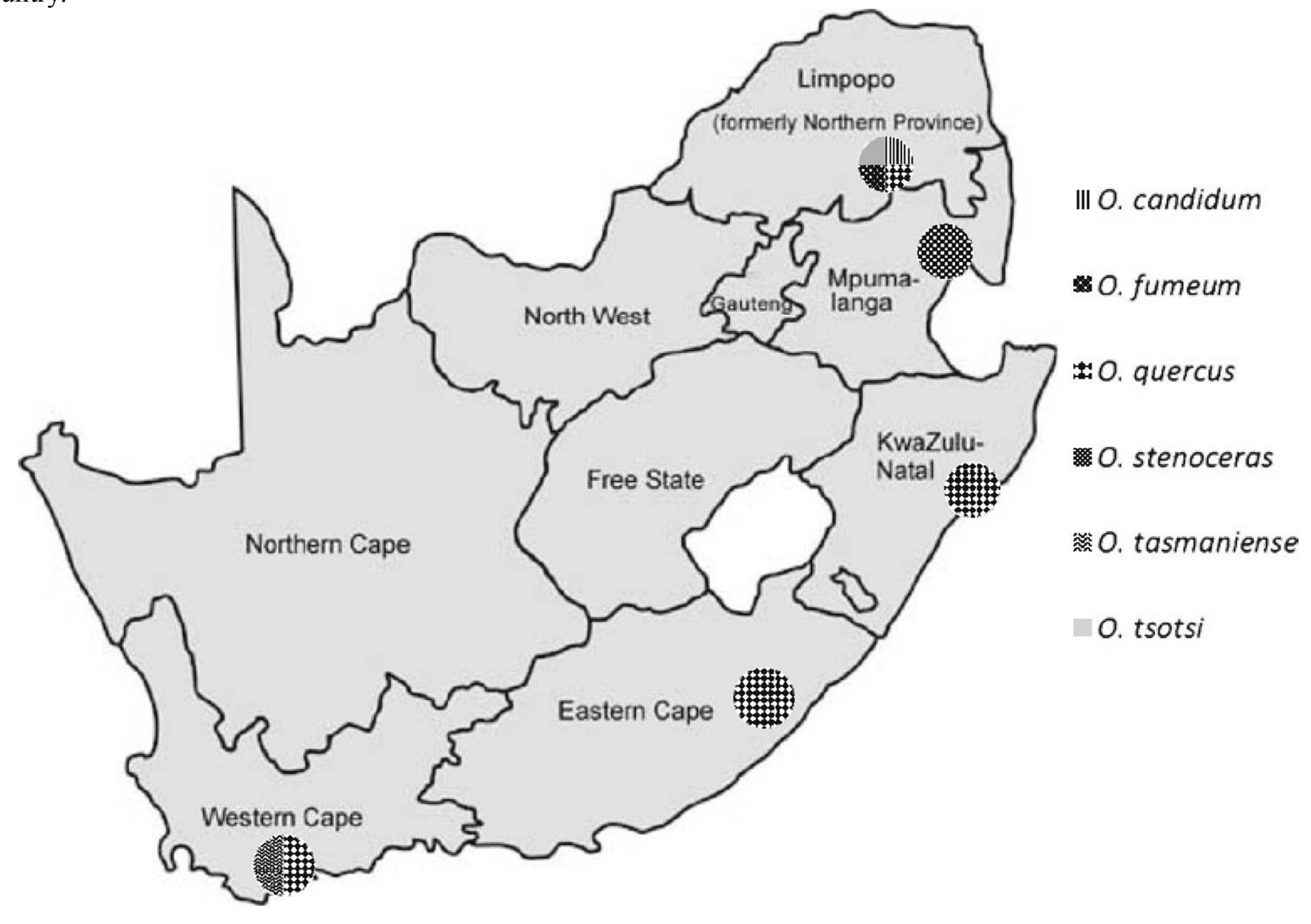

